\title{
Antibiofilm and anticancer activities of unripe and ripe Azadirachta indica (neem) seed extracts
}

\author{
Kartik Chandra Guchhait ${ }^{1}$, Tuhin Manna ${ }^{1}$, Manas Barai ${ }^{2}$, Monalisha Karmakar', Sourav Kumar Nandi ${ }^{3}$, \\ Debarati Jana', Aditi Dey' , Suman Panda', Priyanka Raul', Anuttam Patra ${ }^{5}$, Rittwika Bhattacharya ${ }^{3}$, \\ Subhrangsu Chatterjee ${ }^{4}$, Amiya Kumar Panda ${ }^{2,6}$ and Chandradipa Ghosh ${ }^{1 *}$
}

\begin{abstract}
Background: Antibiotic resistances of pathogens and breast cancer warrant the search for new alternative strategies. Phytoextracts can eradicate microbe-borne diseases as well as cancer with lower side effects compared to conventional antibiotics.

Aim: Unripe and ripe Azadirachta indica (neem) seed extracts were explored as potential antibiofilm and anticancer agents in combating multidrug-resistant infectious bacteria as well as anticancer agents against the MDR breast cancer cell lines.

Methods: Shed-dried neem seeds (both unripe and ripe) were pulverized and extracted using methanol. The chemical components were identified with FTIR and gas chromatography - mass spectrometry. Antibiofilm activity of neem seed extracts were assessed in terms of minimum biofilm inhibitory concentration (MBIC), minimum biofilm eradication concentration (MBEC), and fluorescence microscopic studies on Staphylococcus aureus and Vibrio cholerae. Bacterial cells were studied by fluorescence microscopy using acridine orange/ethidium bromide as the staining agents. Minimum inhibitory concentration (MIC) and minimum bactericidal concentration (MBC) values were evaluated to observe the antibacterial activities. Cytotoxicity of the extracts against human blood lymphocytes and the anticancer activity against drug-resistant breast cancer cell lines were assessed by 3-(4,5-dimethylthiazol-2-yl)-2,5-diphenyltetrazolium bromide (MTT) assay and fluorescence-activated cell sorting (FACS) studies.

Results: 4-Ethyl-2-hydroxy-2-cyclopentene-1-one, phthalic acid, and 2-hexyl-tetrahydro thiophane were the major compounds in unripe neem seed, whereas 3,5-dihydroxy-6-methyl-2,3-dihydro-4-H-pyran-4-one and 4-ethylbenzamide were predominant in ripe neem seed. Triazine derivatives were also common for both the extracts. MBIC values of unripe and ripe neem seed extracts for S. aureus are 75 and $100 \mu \mathrm{g} / \mathrm{mL}$, respectively, and for $V$. cholerae, they are 100 and $300 \mu \mathrm{g} / \mathrm{mL}$, respectively. MBEC values of unripe and ripe seed extracts are 500 and $300 \mu \mathrm{g} / \mathrm{mL}$, respectively for S. aureus and for $V$. cholerae the values are 700 and $500 \mu \mathrm{g} / \mathrm{mL}$, respectively. Fluorescence microscopic studies at 16 and $24 \mathrm{~h}$, after bacterial culture, demonstrate enhanced antibiofilm activity for the ripe seed extract than that of the unripe seeds for both the bacteria. MTT assay reveals lower cytotoxicity of both the extracts towards normal blood
\end{abstract}

\footnotetext{
*Correspondence: ch_ghosh@mail.vidyasagar.ac.in

${ }^{1}$ Department of Human Physiology, Vidyasagar University,

Midnapore 721102, West Bengal, India

Full list of author information is available at the end of the article
}

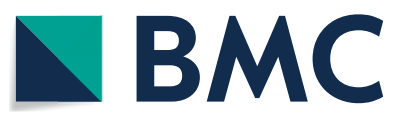

(c) The Author(s) 2022. Open Access This article is licensed under a Creative Commons Attribution 4.0 International License, which permits use, sharing, adaptation, distribution and reproduction in any medium or format, as long as you give appropriate credit to the original author(s) and the source, provide a link to the Creative Commons licence, and indicate if changes were made. The images or other third party material in this article are included in the article's Creative Commons licence, unless indicated otherwise in a credit line to the material. If material is not included in the article's Creative Commons licence and your intended use is not permitted by statutory regulation or exceeds the permitted use, you will need to obtain permission directly from the copyright holder. To view a copy of this licence, visit http://creativecommons.org/licenses/by/4.0/. The Creative Commons Public Domain Dedication waiver (http://creativeco mmons.org/publicdomain/zero/1.0/) applies to the data made available in this article, unless otherwise stated in a credit line to the data. 
lymphocytes, and anticancer activity against breast cancer cell line (MDA-MB-231) with superior activity of ripe seed extract. FACS studies further supported higher anticancer activity for ripe seed extract.

Conclusions: Methanolic extract of neem seeds could substantially inhibit and eradicate biofilm along with their potent antibacterial and anticancer activities. Both the extracts showed higher antibiofilm and antibacterial activity against S. aureus (gram-positive) than $V$. cholerae (gram-negative). Moreover, ripe seed extract showed higher antibiofilm and anticancer activity than unripe extracts.

\section{Keywords: Azadirachta indica, Neem, Bacteria, S. aureus, V. cholerae, Biofilm, Cancer \\ Graphical Abstract}

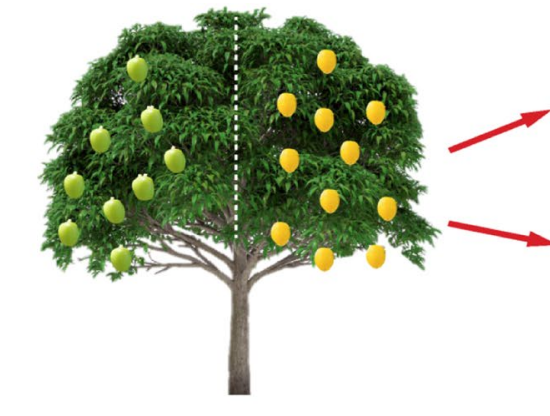

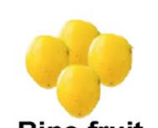

Ripe fruit

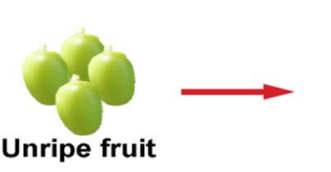

Unripe fruit

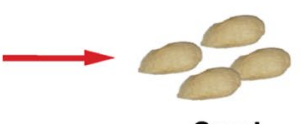

Seed

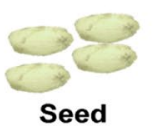

Seed

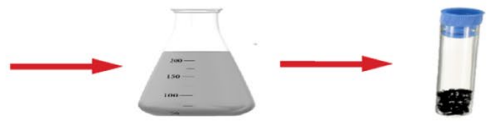

Methanolic extract Drying

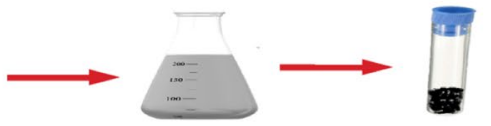

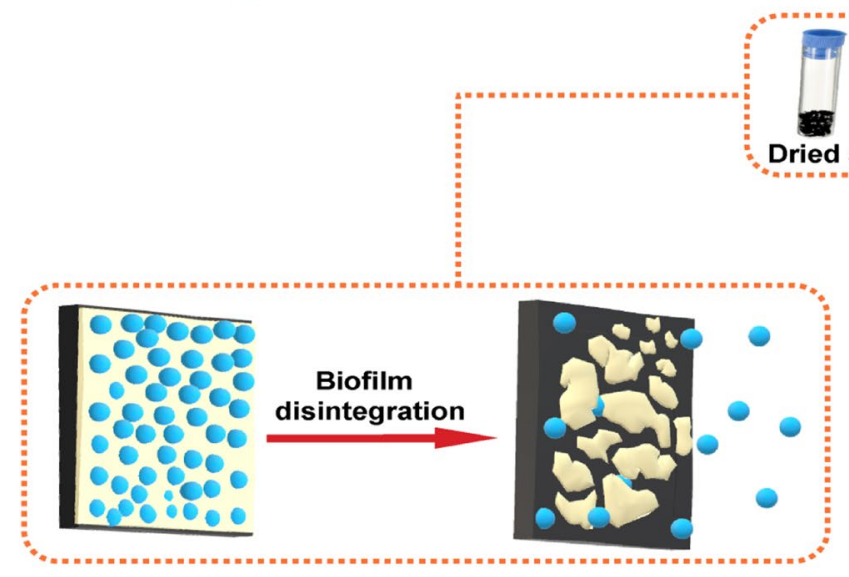

\section{Background}

Bacterial resistances to conventional antibiotics have emerged as one of the burning issues in therapeutic aspects. Remarkable escalation in the appearance of multidrug-resistant bacterial pathogens has caused a life-threatening emergent situation in the therapeutic arena and is responsible for the high rate of mortality, especially for immune-compromised individuals [1]. Development of host antibiotic resistance is caused mostly by their uncontrolled uses and this is mediated by increasing efflux pump activity, several modified enzymes which breaks the antibiotics and/or changing the target of antibiotics [2,3]. Due to the enhanced resistance, it becomes harder to treat common infectious diseases [2, 4]. This situation is not only serious in medical indwelling-related hospital-acquired infections, but also been happening in serious magnitude in the communities [5, 6]. Therefore, effective development of alternative treatment strategies to antibiotics, chemotherapy, in various aspects like organ transplantation, surgeries, and cancer treatment is becoming a concern of towering demand to achieve control over the high risk of multi drug-resistant events. About $80 \%$ of bacterial infections are biofilm-mediated, the ability to form biofilm make the situation graver as bacterial cells in a biofilm can undermine host immune attack and restricts the antimicrobial substances to penetrate the biofilm layer $[3,6,7]$.

Infections caused by Staphylococcus aureus, a grampositive bacterial pathogen, have been indifferent to first-line antibiotics. S. aureus causes severe soft tissue infections in hospital settings and in communities $[8,9]$. As per the report, methicillin-resistant $S$. aureus (MRSA) causes $64 \%$ more death globally than the 
non-resistant counterpart [8]. They cause acute infections like bacteraemia and skin abscesses by secreting several toxins and exo-enzymes [10]. In contrast, chronic infections are associated with a biofilm mode of growth where it can attach and persist on host tissues, such as bone and heart valves, to cause osteomyelitis and endocarditis, respectively, or on implanted medical indwellings, such as catheters, hip prosthetic implants, etc. [6, 10-12]. Among the food pathogens, Vibrio cholerae is a facultative anaerobic, gram-negative human pathogen. It causes pandemic/endemic cholera, cholera-like diarrhoea, and extra-intestinal infections $[13,14]$. Consumption of contaminated water and/or food are the major causes of $V$. cholerae infections and reports reveal that around 1.3 to 4.0 million people get infected by them every year all over the world [15]. In inter-epidemic periods, $V$. cholerae can survive long in their natural habitats by virtue of their ability to form biofilm and hence, they could be potential threats in causing widespread infection in near future by evolving as an epidemic clone. Continued researches on emerging strains of $V$. cholerae have demonstrated a high frequency of emergence of multidrug-resistant strains [15, 16].

Report reveal that more than $60 \%$ infections caused by bacteria are biofilm based [17]. Biofilm is a cage-like structure formed by bacteria for its survival inside the host. This occurs through the creation of a matrix-like structure that covers and protects bacteria against different toxic agents or antimicrobial compounds as well as helps to access different nutrients $[18,19]$. Consequently, biofilm formation in bacteria creates a suitable environment for their persistence and enhances their virulence properties $[20,21]$. The extracellular matrix acts as a physical barrier that reduces the direct effects of antibiotics on bacterial cells $[22,23]$. This physical barrier prevents antibiotics to enter into the core zone of biofilm. As a result, bacterium wins against the killer-antibiotics [24]. Common antibiotics normally kill planktonic cells and the majority of biofilm structures. However, the bacteria those can successfully survive even after the drug treatment, start a new cycle of biofilm development by repopulating the biofilm and disseminating into planktonic forms [25]. This eventually enhances the ailment process caused by biofilm-forming pathogenic microorganisms.

Beside the threat of antibacterial resistance, cancer is another health burden despite the improvement of diagnosis and modern surgical processes [26, 27]. Cancer cells are heterogeneous due to altered micro-environment and clonal evolution [28]. Under-developed and developing countries are more susceptible to cancer as a result of poor lifestyles and "westernized" diets [29]. It has been reported that $70 \%$ of cancer deaths occur in
Africa, Asia, as well as in Central and South America [30]. Breast cancer is one of the most common cancers among women worldwide, accounting for approximately 5.7 million deaths [31]. Over 1.5 million women (25\% of all women with cancer) are diagnosed with breast cancer every year globally [31, 32]. Breast cancer is metastatic and can commonly transfer to distant organs such as the bone, liver, lung, and brain, which mainly accounts for its incurability. Although chemotherapy and several anticancer drugs are available, their adverse side effects on normal cells/tissue, such as bone marrow function inhibition, nausea, vomiting, and alopecia lead scientists to search for some alternative therapies, which has little or no major health concern [33].

The aforementioned scenario has encouraged the present research group to make a target in identifying new bioactive compounds against the pathogenic bacterial infections as well as to target breast cancer. Inhibition of biofilm formation serves as a novel strategy to successfully combat bacteria bypassing the chance to generate bacterial resistance due to the minute or no pressure it exerts upon bacterial cell [34]. On the other hand, inhibition of proliferation and induction of cancerous cell death are the vital targeting area to control as well as to eradicate the cancerous cells [35]. Natural products have been playing important roles in exploring and processing of new drugs against bacterial infections and cancer development as their mode of action reduces the emergence of bacterial antibiotic resistance and abnormal cell progression, respectively $[35,36]$.

A growing number of evidences clarified that plant extracts possess considerable antimicrobial and anticancer potentials without any significant risk of resistance development against them [35, 37-39]. Besides, they are expected to have lower side effects. Plant-derived quinones, flavonoids, polyphenol, essential oils and tannins are known to complex with the cell wall synthesizing enzymes, inactivating it and thereby causes disruption of the microbial cell wall [40]. Alkaloids get intercalated into the membranes and destabilize them [40]. Polyphenols and tannins cause metal ion complexation and substrate deprivation to their target pathogens [41]. One of the rich sources of natural products is Azadirachta indica (neem) that has different beneficial properties in Indian as well as in African traditions [42]. Flowers, leaves, seeds, and bark of this plant have extensively been used as insecticide, antimicrobial, larvicidal, antimalarial, antibacterial, antiviral, and anticancer agent [43]. Components of neem are known to inhibit cancer progression as studied both in-vitro and in-vivo [44]. About 300 components have so far been identified from neem [45]. In spite of its tremendous potential, all the components and biological potentials are yet to be fully explored [45]. Proper 
comparative evaluation of unripe and ripe seed extracts is also so far illusive. Hence, the current study endeavours to delineate the potential of the methanolic extracts of neem seeds against two potent human pathogenic bacteria, i.e., S. aureus and V. cholerae, as antibiofilm agent, and also against breast cancer cells as anticancer agent. S. aureus, the Gram-positive and V. cholerae, the Gramnegative bacterial isolates were included in the study on the basis of their high biofilm forming abilities [46, 47]. A wide range of phytochemicals, both polar and nonpolar, can easily be extracted using methanol and also it has low boiling point that prevents the phytochemicals from damage during evaporation [48]. Antibiofilm activity of the extracts was assessed by spectrophotometric studies and fluorescence microscopy. MTT assessment was carried out on human blood lymphocytes to assess the biocompatibility of the extracts. Anticancer activity on MDA-MB-231 triple-negative breast cancer cell lines were carried out by combined methods of MTT and FACS analyses. Results from these analyses are expected to emphasize the future uses of neem seed against bacterial infection as the extract has lower side effects and easier availability.

\section{Experimental section \\ Materials}

Methanol and potassium bromide $(\mathrm{KBr})$ were purchased from Merck Limited, Mumbai, India. Roswell Park Memorial Institute medium (RPMI) and dimethyl sulfoxide (DMSO), 3-[4,5-dimethylthiazol-2-yl]-2,5-diphenyltetrazolium bromide (MTT), Luria-Bertani (LB) broth, and LB agar were procured from Hi-Media Laboratories, Mumbai, India. They were of AR grade and were used as received.

\section{Methods}

\section{Collection of Azadirachta indica (neem) seed} and extraction with methanol

Unripe and ripe Azadirachta indica fruits were collected in the month of April, 2019 from the campus of Vidyasagar University, Midnapore, West Bengal, India in two phases from the same tree. The plant was duly identified and authenticated by the Department of Botany, University of Calcutta, West Bengal, India vide accession no: CUH20098(CUH). All methods were performed in accordance with the relevant guidelines and regulations.

The unripe and ripe neem seeds were separately washed with water and then shed-dried for fifteen days at room temperature with little modification of method described previously [49]. 200 g dried seeds were then pulverized for 2 min using a blender. $50 \mathrm{~g}$ of powdered seed was mixed with $150 \mathrm{~mL}$ of HPLC grade methanol and incubated at $37^{\circ} \mathrm{C}$ under shaking condition for $48 \mathrm{~h}$.
Methanol was evaporated from the filtrate of the extract. It was then dried under vacuum overnight to remove further traces of the solvent. The crystal-like crude extracts (2.2 and 2.6 gm of unripe and ripe extracts, respectively) were then stored in properly-labelled amber bottles at $4^{\circ} \mathrm{C}$ under nitrogen atmosphere prior to use.

\section{FTIR studies}

Identification of different functional groups in the methanolic extracts of both the unripe and ripe neem seeds were carried out by FTIR spectroscopy (Lambda, Perkin Elmer Spectrophotometer, USA) in the range of 3500$400 \mathrm{~cm}^{-1}$ [50]. $\mathrm{KBr}$ disks containing solid extract material was prepared and used for FTIR studies.

Gas Chromatography - Mass Spectrometry (GC-MS) studies GC-MS analyses of neem seed extracts were performed on a Clarus 600 GC (Perkin Elmer, USA) System, fitted with a non-polar capillary column, coupled to a Clarus $600 \mathrm{C}$ MS. Helium was used as the carrier gas at a constant flow rate of $1.0 \mathrm{~mL} / \mathrm{min}$ [51]. The injection and ion source temperatures were 270 and $230^{\circ} \mathrm{C}$, respectively. The ionizing energy was set at $70 \mathrm{eV}$. Oven temperature was programmed from $60^{\circ} \mathrm{C}$ (hold for $2 \mathrm{~min}$ ) to $260^{\circ} \mathrm{C}$ at a rate of $3{ }^{\circ} \mathrm{C} / \mathrm{min}$. The crude samples were diluted with methanol $(1: 100, v / v)$ and filtered, particle-free dilute seed extracts were taken in a syringe and injected into the injector with a split ratio of 20:1. The mass spectra were computer matched with those of standards available in mass spectrum libraries (National Institute of Standards and Technology (NIST) Mass Spectral Library).

\section{Cytotoxicity assessment of phytoextracts against human blood lymphocytes}

Blood samples were collected from healthy adult human volunteers by venipuncture in $5 \mathrm{~mL}$ heparin-containing tubes. Blood was collected from all human subjects with informed consent following all relevant guidelines and regulations. Experimental protocols in this regard were approved by Institutional Ethics Committee of Vidyasagar University, West Bengal, India. $5.0 \mathrm{~mL}$ of blood was diluted (1:1) with phosphate-buffered saline (PBS) and layered on Histopaque 1077 (Sigma-Aldrich, USA) by using a Pasteur pipette and centrifuged at $1500 \mathrm{rpm}$ for $40 \mathrm{~min}$ at room temperature. The upper layer of the buffy coat (lymphocytes) was transferred using a clean Pasteur pipette to a clean centrifuge tube. It was washed three times and then resuspended in RPMI complete media supplemented with $10 \%$ fetal bovine serum (FBS) to incubate for a day at $37^{\circ} \mathrm{C}$ in a $5 \% \mathrm{CO}_{2}$ incubator [52]. Cytotoxicity of both unripe and ripe crude extracts were quantitatively estimated by colorimetric assay systems using MTT [53]. Optical density (OD) of the samples 
were measured on ELISA reader (BIO-RAD, Model 550, USA) using test and reference wavelengths of 570 and $630 \mathrm{~nm}$, respectively. Percentage of cell viability was calculated by using the following equation [52]:

$$
\text { Cell viability } \%=\left[\mathrm{OD}_{\text {sample }}-\mathrm{OD}_{\text {control }}\right] \times 100 / \mathrm{OD}_{\text {control }}
$$

\section{Bacterial strains and growth conditions}

Staphylococcus aureus D1 and Vibrio cholerae TM8 bacterial strains were chosen from laboratory collections of present research group, based on their ability to produce high biofilm [46, 47, 54]. The Staphylococcus aureus D1 [46] and Vibrio cholerae TM8 [47] strains were isolated from pus and stool samples, respectively in clinical settings from hospitalized patients following research ethical guidelines and consent from appropriate authorities. For routine growth purposes, $S$. aureus and $V$. cholerae strains were cultured using Luria-Bertani (LB) broth and $\mathrm{LB}$ agar plates at $37^{\circ} \mathrm{C}[54]$.

\section{Inhibition of biofilm formation}

Effects of the methanolic extracts of unripe and ripe neem seeds on biofilm formation were tested by determining their minimum biofilm inhibitory concentration (MBIC) using the modified microdilution method [55]. Briefly, different concentrations of each methanolic neem seed extracts were prepared in such a way that the final concentration was in the range of 50 to $500 \mu \mathrm{g} / \mathrm{mL}$.

Bacterial cultures were prepared by inoculating bacterial samples in test tubes containing $5 \mathrm{~mL}$ LB broth and keeping it overnight in a shaking incubator at $37^{\circ} \mathrm{C} .5 \mu \mathrm{L}$ of bacterial culture was added in $490 \mu \mathrm{L}$ broth and $5 \mu \mathrm{L}$ of different concentrations of neem seed extracts (unripe and ripe, respectively) were separately added to test tubes so that the final volume of the tubes become $500 \mu \mathrm{L}$. PBS was used as negative control instead of the plant extracts. Samples were then incubated at $37^{\circ} \mathrm{C}$ for $18 \mathrm{~h}$ in static condition. Modified crystal violet assay was performed to quantify biofilm formation [56]. OD values and the changes of biofilm ring in the LB tubes were shown in Table S1 and Fig. S2, respectively (Supplementary section). Biofilm inhibition percentage was calculated as follows [55]:

Inhibition $\%=\left(\mathrm{OD}_{\text {untreated }}-\mathrm{OD}_{\text {treated }}\right) / \mathrm{OD}_{\text {untreated }} \times 100 \%$

\section{Inhibition of preformed biofilms}

Biofilms were pre-formed in a borosilicate glass tube by aliquoting $50 \mu \mathrm{L}$ of standardized $V$. cholerae and $S$. aureus $\left(1.0 \times 10^{7} \mathrm{CFU} / \mathrm{mL}\right)$ and incubated for $4 \mathrm{~h}$ at $37^{\circ} \mathrm{C}$. Sufficient biofilm biomass was observed within this time, as also supported by others (55). Following incubation, $50 \mu \mathrm{L}$ of each of the neem seed extracts were added to the tubes. The tubes were further incubated for $24 \mathrm{~h}$ at 37 ${ }^{\circ} \mathrm{C}$ [54]. After the incubation period, crystal violet assay was performed to quantify biofilm biomass [57]. OD values and the changes of biofilm ring in the LB tubes were shown in Table S2 and Fig. S3, respectively. Finally, minimum biofilm eradication concentration (MBEC) of the extracts was determined using Eq. (2).

\section{Antibacterial activities}

MIC and MBC values were evaluated by the microdilution method in LB $[58,59]$. The MBC values of the extracts were obtained by sub-culturing the MIC dilutions onto the sterile Mueller Hinton agar plates and incubated at $37^{\circ} \mathrm{C}$ for $24 \mathrm{~h}$. The lowest concentration of the extracts, in which no bacterial colony was found, and the bacteria were completely killed was considered as MBC.

\section{Fluorescence microscopic studies}

Biofilms of both $V$. cholerae and $S$. aureus were visualized by fluorescence microscopy using 4,6-diamidino-2-phenylindol (DAPI), which stains the cells and extracellular matrix by passing through the cell membrane and allows the microscopic detection of the biofilm [60]. In brief, a glass surface was used as the substratum for biofilm development. Bacterial biofilms prepared on glass surface were washed with PBS once and covered with DAPI solution $(0.01 \% \mathrm{w} / \mathrm{v})$ for $10 \mathrm{~min}$ in the dark. The slide was then washed with PBS as well as sterile distilled water; and was dried before observation under a fluorescence microscope (Axio Scope A1, Zeiss, Oberkochen, Germany). To visualize the antibiofilm activity of both unripe and ripe extract, fluorescence imaging was performed using Axiocam 305 in the time gap of 8, 16, and $24 \mathrm{~h}$ for both the bacterial cells. To visualize and compare the antibiofilm activity of both extracts, the plant extracts were added in the same concentration $(100 \mu \mathrm{g} /$ $\mathrm{mL}$ ) during the inoculation of each bacterium. Live and dead bacterial cells were examined by acridine orange $(\mathrm{AO}) /$ ethidium bromide $(\mathrm{EB})$ staining with proper precautions for both $V$. cholerae and S. aureus to discriminate between the live (AO stained) and dead (EB stained) bacterial cells [61]. Overnight grown bacterial cells (107 cells $/ \mathrm{mL}$ ) were treated with unripe and ripe extracts (at their MIC values) for $15 \mathrm{~min}$ at $37^{\circ} \mathrm{C}$. After incubation, cells were harvested by centrifugation, washed with PBS, and stained with $\mathrm{AO} / \mathrm{EB}(1: 1)(100 \mathrm{mg} / \mathrm{mL})$ for $30 \mathrm{~min}$. After 30 min incubation, cells were washed with PBS and visualized under the fluorescence microscope using blue filter $(480 \mathrm{~nm})$. 


\section{Cell culture}

Human breast cancer cell line, MDA-MB-231 (ATCC ${ }^{\circledR}$ HTB-26 ${ }^{\mathrm{TM}}$ RRID: CVCL_0062), extremely invasive breast carcinoma cell, was obtained from National Centre for Cell Science (NCCS), Pune, India. The cells were passaged at sub-confluence in T-25 flasks with Dulbecco's modified eagle medium (DMEM) supplemented with $10 \%(v / v)$ heat-inactivated fetal bovine serum (SigmaAldrich), $2 \mathrm{mM}$ glutamine, $1 \%(v / v)$ penicillin and streptomycin and maintained at $37^{\circ} \mathrm{C}$ in a humidified incubator with $5 \% \mathrm{CO}_{2}$. Low-passage cells were grown about approximately $70-80 \%$ confluency at previously described protocol $[62,63]$.

\section{Cell viability assay}

Viable cell number was investigated through MTT assay [64]. The confluent MDA-MB-231 cells were plated in a concentration of $1 \times 10^{6}$ cells $/ \mathrm{mL}$ in a 96 well plate. After $24 \mathrm{~h}$ of growth, experimental cells were treated with variable concentrations of control drug (gemcitabine) and plant extracts (dissolved in DMSO) for $24 \mathrm{~h}$. After drugtreatment, the cells were incubated with $10 \mu \mathrm{L}$ of MTT $(5 \mathrm{mg} / \mathrm{mL})$ at $37{ }^{\circ} \mathrm{C}$ for $4 \mathrm{~h}$. All the tests were performed in triplicate. Absorbance (at $570 \mathrm{~nm}$ ) for each concentration was determined and their cell viabilities were calculated (in percentage, \%) with respect to the blank $[65,66]$ using Eq. (1).

\section{Flow cytometric analysis of cell surface markers CD44 and CD326}

Immunophenotyping is a useful method for the detection of cell surface-marker through flow cytometry or FACS. MDA-MB-231 cells $\left(1.0 \times 10^{5}\right.$ cells $\left./ \mathrm{mL}\right)$ were eroded with PBS and then harvested with trypsinEDTA (Thermo Fisher Scientific, Ca \# 25,300,054), at a concentration of $2.2 \mathrm{mM}$ [67]. Ingathered cells were re-suspended in PBS with $0.5 \%$ fetal bovine serum with DMEM. To detect expression of fluorochrome-conjugated antibodieanti-CD44 (FITC-conjugated, Abcam, Ca \# ab189524), and anti-CD326 (EpCAM, Abcam, Ca \# ab239311) were added to the cell suspension, as recommended by the manufacturer, and incubated at $4{ }^{\circ} \mathrm{C}$ in the dark for 30-40 min. Cells without/with the drugs were washed and supernatants were aspirated out. Cells were then washed with sheath solution and incubated with antibody CD44, CD326 (EpCAM) in the dark for $15 \mathrm{~min}$. Further, the cells were washed and dissolved in $500 \mu \mathrm{L}$ sheath solution and finally analyzed using BD LSRFortessa $^{\mathrm{TM}}$ SORP (San Jose, CA) cell analyzer and BD FACS Diva v8.0.1 software as previously established protocol [67].

\section{Statistical analysis}

The mean values and standard deviations of each quantitative variable were calculated after repeating each experiment three times. All the quantitative data were represented as mean \pm standard deviation (SD). Statistical analyses were performed using Microsoft Excel. Two -tail Student's t test was performed to compare the percent of biofilm inhibition/eradication by uniripe and ripe seed extracts for both bacteria. Differences were considered significant at $P<0.05$.

\section{Results \\ FTIR Analysis}

FTIR studies were performed to identify different functional groups in the methanolic extract of the seeds, as shown in Fig. 1. The $\mathrm{C}-\mathrm{O}$ stretch in hydroxyl compound can be ascribed to the strong band that appeared at $1026 \mathrm{~cm}^{-1}$. The band around $1238 \mathrm{~cm}^{-1}$ is due to the presence of $\mathrm{C}=\mathrm{O}$ groups in aromatic ester and $\mathrm{C}-\mathrm{N}$ groups in amine moieties. In the unripe extract, the strong peak appeared at $1407 \mathrm{~cm}^{-1}$ that could be assigned to stretching vibrations of $\mathrm{C}-\mathrm{H}$ and $\mathrm{O}-\mathrm{H}$ bonds. The band around $1500-1600 \mathrm{~cm}^{-1}$ signifies aromatic rings $\mathrm{C}=\mathrm{C}$ stretching vibration, enhanced by polar functional groups $[68,69]$. Interestingly, only the ripe extract shows the characteristic band at $1667 \mathrm{~cm}^{-1}$ that represents the amide groups. Table 1 for ripe fruit reveals two amides (please see the following Sect. 3.2. GC-MS analyses), having peaks at 1662 and $1671 \mathrm{~cm}^{-1}$ (blue line in Fig. 1). The strong band appeared around $1731 \mathrm{~cm}^{-1}$ confirmed the presence of $\mathrm{C}=\mathrm{O}$ bonds in ketones, aldehyde, and lactone [68]. Both the unripe and ripe seed extracts possess alkyl chain. The weak peak in both the samples had appeared at $2929 \mathrm{~cm}^{-1}$ for asymmetrical and at $2884 \mathrm{~cm}^{-1}$ for symmetrical stretching vibration can be attributed to $\mathrm{C}-\mathrm{H}$ (methylene groups). The broad band around $3296 \mathrm{~cm}^{-1}$ was due to the $\mathrm{O}-\mathrm{H}$ stretching mode of hydroxyl and $\mathrm{N}-\mathrm{H}$ stretching mode of amine groups. Alkaloids, phenols, triterpenoids, tannins, oxalates, saponins, and flavonoids were previously reported in the methanolic neem seed extract [70].

\section{GC-MS analyses}

Methanolic extracts of both the unripe and ripe neem seeds were subjected to GC-MS analyses in identifying different active components (Fig. 2) and were further correlated with the FTIR data. In case of unripe neem seed, seven major compounds were detected as summarized in Table 2. 4-Ethyl-2-hydroxy-2-cyclopentene-1-one, phthalic acid, and 2-hexyl-tetrahydothiophane were the most abundant phytochemicals. Phthalic acid derivatives are reported to have antimicrobial activities both on 
Table 1 Chemical composition of methanolic extract of ripe neem seed detected by GC-MS analysis

\begin{tabular}{|c|c|c|c|c|c|c|c|}
\hline Retention Time & $\begin{array}{l}\text { Name of the } \\
\text { Compound }\end{array}$ & $\%$ Area & $\begin{array}{l}\mathrm{MW} \\
(\mathrm{Da})\end{array}$ & Molecular formula & Chemical class & $\begin{array}{l}\text { Expected FTIR } \\
\text { spectra }\left(\mathrm{cm}^{-1}\right)\end{array}$ & Biological activities \\
\hline 5.15 & 1-methylpyrrol & 2.18 & 81 & $\mathrm{C}_{5} \mathrm{H}_{7} \mathrm{~N}$ & $\begin{array}{l}\text { Heterocyclic com- } \\
\text { pound }\end{array}$ & $\begin{array}{l}1509,1266,1090 \\
724,606\end{array}$ & $\begin{array}{l}\text { Antimicrobial and } \\
\text { anticancer activity [83] }\end{array}$ \\
\hline 17.12 & $\begin{array}{l}\text { 3,5-dihydroxy- } \\
\text { 6-methyl-2,3-dihy- } \\
\text { dro-4 H-pyran-4-one }\end{array}$ & 11.41 & 144 & $\mathrm{C}_{6} \mathrm{H}_{8} \mathrm{O}_{4}$ & Flavonoids & 1720,1655 & $\begin{array}{l}\text { Antibacterial, antioxi- } \\
\text { dant and anticancer } \\
\text { activity [84] }\end{array}$ \\
\hline 26.38 & $\begin{array}{l}\text { 2-hydroxy-n-3,3-tri- } \\
\text { methyl-butanamide }\end{array}$ & 1.8 & 145 & $\mathrm{C}_{7} \mathrm{H}_{15} \mathrm{NO}_{2}$ & n-acyl amines & $\begin{array}{l}3366,3164,2962, \\
1662,1634,1430 \\
1418,1263\end{array}$ & \\
\hline 26.67 & 4-ethylbenzamide & 4.75 & 149 & $\mathrm{C}_{9} \mathrm{H}_{11} \mathrm{NO}$ & Phenolic compound & $\begin{array}{l}3343,3168,1671 \\
1618,1414,1398\end{array}$ & Antitumor activity [85] \\
\hline
\end{tabular}

*All the compounds were selected according to the peak area percentage in the GC-MS data. Compounds were cross-checked with their expected FTIR spectra in Fig. 1

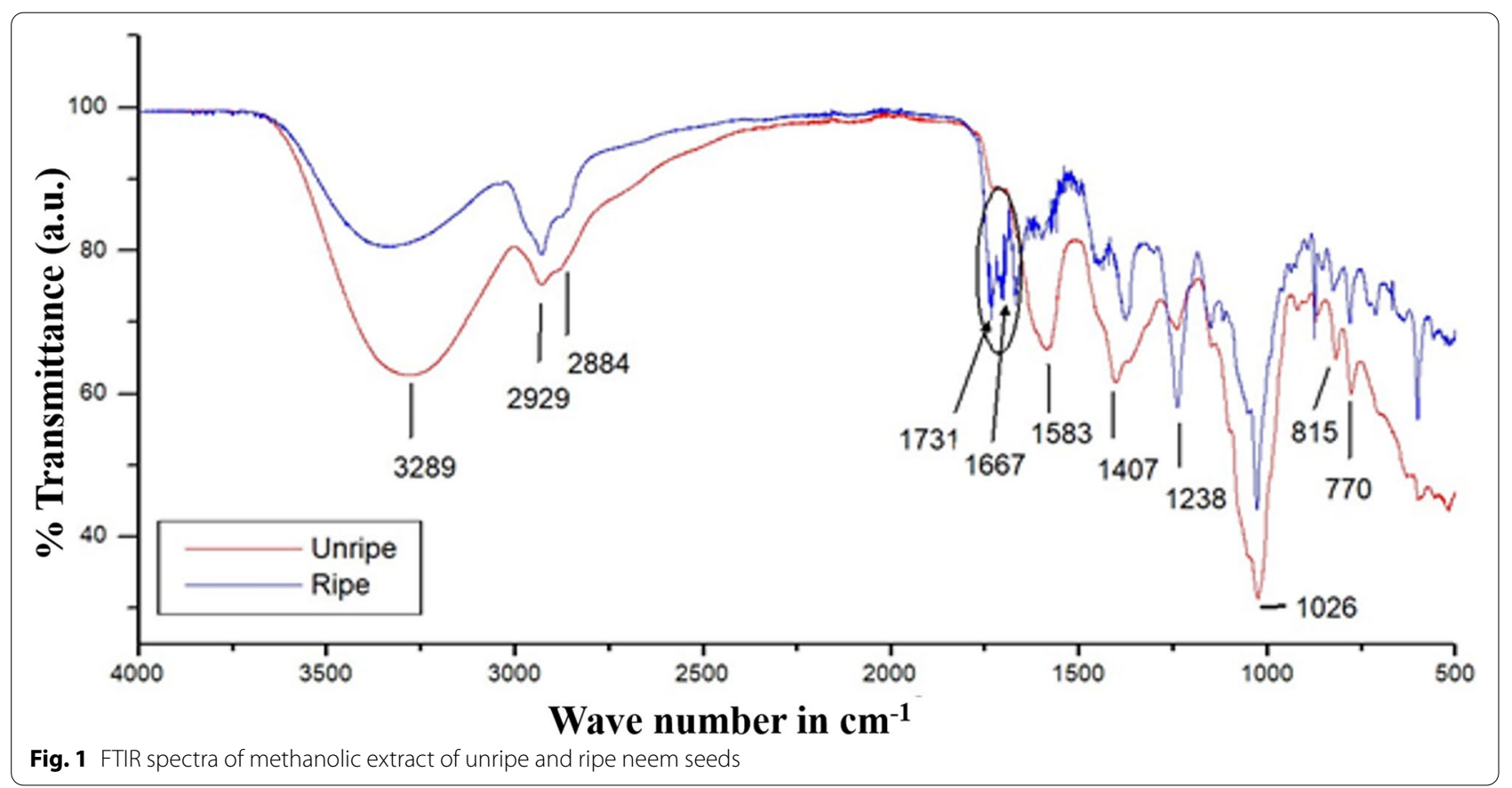

gram-positive and gram-negative bacteria [71]. 2-Hexyltetrahydrothiophane has antimicrobial, anticancer as well as antifungal properties [72, 73]. On the other hand, four major compounds were found in the ripe seed extract (Table 1), in which 3,5-dihydroxy-6-methyl-2,3-dihydro-4 $\mathrm{H}$-pyran-4-one and 4-ethylbenzamide were the predominant components. 3,5-Dihydroxy-6-methyl2,3-dihydro-4 H-pyran-4-one is reported as potent antioxidant agent [74]. 4-ethylbenzamide has both antitumor and antimicrobial activities [75]. Triazine derivatives were found to be the common compound for both the extracts. The expected FTIR peaks of all the above-mentioned suggested compounds were listed in Tables 2 and 1. It was found that all these expected peaks are present in the recorded FTIR spectra (Fig. 1), a further support that the suggested compounds are indeed present in the extracts obtained.

\section{Cytotoxicity studies}

MTT assay on human blood lymphocytes was performed to determine the cellular toxicity levels of the methanolic extracts of neem seeds. At $5 \mathrm{mg} / \mathrm{mL}$ dosage, cell viabilities were 83.65 and $82.22 \%$ for unripe and ripe extracts, respectively. At the highest dosage $(20 \mathrm{mg} / \mathrm{mL})$, the cell viabilities were 71.42 and $70.38 \%$, respectively for unripe and ripe neem extracts (Fig. 3). No significant morphological difference of the lymphocytes was seen under light microscope (Fig. S1, Supplementary section). To 
Table 2 Chemical composition of methanolic extract of unripe neem seed detected by GC-MS analysis

\begin{tabular}{|c|c|c|c|c|c|c|c|}
\hline Retention Time & $\begin{array}{l}\text { Name of the } \\
\text { Compound }\end{array}$ & $\%$ Area & $\begin{array}{l}\mathrm{MW} \\
(\mathrm{Da})\end{array}$ & Molecular formula & Chemical class & $\begin{array}{l}\text { Expected FTIR } \\
\text { spectra }\left(\mathrm{cm}^{-1}\right)\end{array}$ & Biological activities \\
\hline 10.13 & 4-aminopyrimidine & 3.48 & 95 & $\mathrm{C}_{4} \mathrm{H}_{5} \mathrm{~N}_{3}$ & Pyrimidine alkaloids & $\begin{array}{l}3361,3169,1650 \\
1577,1563,1460,804\end{array}$ & $\begin{array}{l}\text { Antibacterial activity } \\
\text { [76] }\end{array}$ \\
\hline 13.02 & $\begin{array}{l}\text { 2-oxo-2,3-dihy- } \\
\text { dro-1 } \mathrm{H} \text { imidazole- } \\
\text { 4-carbonitrile }\end{array}$ & 1.05 & 109 & $\mathrm{C}_{4} \mathrm{H}_{3} \mathrm{~N}_{3} \mathrm{O}$ & & $3456-2778,1642,956$ & $\begin{array}{l}\text { Antimicrobial activity } \\
\text { and antioxidant activity } \\
\text { [77] }\end{array}$ \\
\hline 17.53 & $\begin{array}{l}\text { 1-napthyl acetoxy } \\
\text { acetate }\end{array}$ & 4.61 & 244 & $\mathrm{C}_{14} \mathrm{H}_{12} \mathrm{O}_{4}$ & Ester compound & $\begin{array}{l}1753,1699,1378 \\
1215,1077,1045,777\end{array}$ & $\begin{array}{l}\text { Antibacterial activity } \\
\text { [78] }\end{array}$ \\
\hline 20.16 & $\begin{array}{l}\text { 4-ethyl-2-hydroxy- } \\
\text { 2-cyclopentene- } \\
\text { 1-one }\end{array}$ & 8.65 & 126 & $\mathrm{C}_{7} \mathrm{H}_{10} \mathrm{O}_{2}$ & Carbonyl compound & $\begin{array}{l}2918,1705,1673 \\
1626,1436,1284 \\
1182,840\end{array}$ & $\begin{array}{l}\text { Antibacterial activity } \\
\text { [79] }\end{array}$ \\
\hline 26.14 & phthalic acid & 11.73 & 344 & $\mathrm{C}_{21} \mathrm{H}_{28} \mathrm{O}_{4}$ & $\begin{array}{l}\text { Aromatic dicarboxylic } \\
\text { acid }\end{array}$ & $\begin{array}{l}3094,3013,2896 \\
1701,1687,1678 \\
1405,1283,740\end{array}$ & $\begin{array}{l}\text { Antimicrobial activity } \\
\text { [80] }\end{array}$ \\
\hline 26.55 & $\begin{array}{l}\text { 3,7-dimethyl-(1,2,4)- } \\
\text { triazolo-(4,3-b)-(1,2,4)- } \\
\text { triazine }\end{array}$ & 3.41 & 149 & $\mathrm{C}_{6} \mathrm{H}_{7} \mathrm{~N}_{5}$ & $\begin{array}{l}\text { Poly nitrogen con- } \\
\text { taining heterocycles }\end{array}$ & $\begin{array}{l}1571,1553,1474 \\
1401\end{array}$ & Anticancer activity [81] \\
\hline 27.24 & $\begin{array}{l}\text { 2-hexyl-tetrahydrothi- } \\
\text { ophane }\end{array}$ & 13.55 & 172 & $\mathrm{C}_{10} \mathrm{H}_{2} \mathrm{OS}$ & $\begin{array}{l}\text { Heterocyclic com- } \\
\text { pound }\end{array}$ & $\begin{array}{l}2963,2951,1454 \\
1440,1254\end{array}$ & $\begin{array}{l}\text { Antimicrobial activity } \\
\text { [82] }\end{array}$ \\
\hline
\end{tabular}

*All the compounds were selected according to the peak area percentage in the GC-MS data. Compounds were cross-checked with their expected FTIR spectra in Fig. 1

use the phytoextracts as antibiofilm agents, it preferably should have low cytotoxicity. Results clearly indicate that the extracts can safely be used for future studies at substantially higher concentrations.

\section{Minimum biofilm inhibitory concentration (MBIC)}

The minimum concentration that inhibits the formation of biofilm by $\geq 50 \%$ is considered as the MBIC [86]. MBIC values of the unripe and ripe neem seed extracts on $S$. aureus were 100 and $75 \mu \mathrm{g} / \mathrm{mL}$, respectively (Fig. $4 \mathrm{~A}$ ). In the case of $V$. cholerae, it was 300 and $100 \mu \mathrm{g} / \mathrm{mL}$, respectively (Fig. 4B). MBIC of vancomycin against $S$. aureus has been reported to be $16 \mu \mathrm{g} / \mathrm{mL}$ [87]. Results suggest that the ripe seed extract was more potent as an antibiofilm agent as they could show significant higher percentage of inhibition of biofilm $(P<0.05)$ at all the concentrations than unripe seed extract. Though both kinds of seed extracts exhibited inhibitory effects on biofilm formation on both the bacteria, antibiofilm efficacy was found to be higher in case of S. aureus than $V$. cholerae (Fig. 4). It, therefore, could be concluded that ripening may have transformed certain bioactive components, and those might be responsible for such outcome. However, further thorough studies are required in identifying the components through other analytical tools.

\section{Minimum biofilm eradication concentration (MBEC) studies}

MBEC is defined as the concentration that shows $\geq 50 \%$ eradication of preformed biofilm [88]. MBEC values of methanolic unripe neem seed extract were 500 and $700 \mu \mathrm{g} / \mathrm{mL}$ for S. aureus (Fig. $5 \mathrm{~A}$ ) and V. cholerae (Fig. 5B), respectively. On the other hand, in the case of ripe neem seed extract, MBEC were 300 and $500 \mu \mathrm{g} / \mathrm{mL}$ for $S$. aureus and $V$. cholerae, respectively (Fig. 5). Both unripe and ripe extracts showed higher biofilm eradication efficiency for $S$. aureus than $V$. cholerae. Here also results suggest that the ripe seed extract is more effective as biofilm eradication agent as they could show significant higher percentage of eradication of preformed biofilm $(P<0.05)$ at all the concentrations than unripe seed extract. MBEC of vancomycin against $S$. aureus is $>256 \mu \mathrm{g} / \mathrm{mL}$ [87] and that for doxycycline is $32 \mu \mathrm{g} / \mathrm{mL}$ against $V$. cholerae [89].

\section{Antibacterial activity}

Apart from exploring the antibiofilm activity, the ability of neem seed extracts to inhibit bacterial growths was also studied. MIC value is the lowest concentration that lacks turbidity and is fully transparent and corresponds to $99 \%$ of bacterial growth inhibition [90]. MIC values of ripe neem seed extracts are 1.2 and $2.0 \mathrm{mg} / \mathrm{mL}$ and $\mathrm{MBC}$ values are 2.4 and $4.0 \mathrm{mg} / \mathrm{mL}$ for $S$. aureus and $V$. cholerae, respectively. MIC values of unripe neem seed extracts are 6.0 and $8.5 \mathrm{mg} / \mathrm{mL}$, and $\mathrm{MBC}$ values are 12.0 and $17.0 \mathrm{mg} / \mathrm{mL}$ for $S$. aureus and $V$. cholerae, respectively. Results indicate that ripe neem seed extracts possess higher antibacterial activity than the unripe seed extracts against the specified bacterial strains. Ripening of the neem seed altered the secondary metabolite 


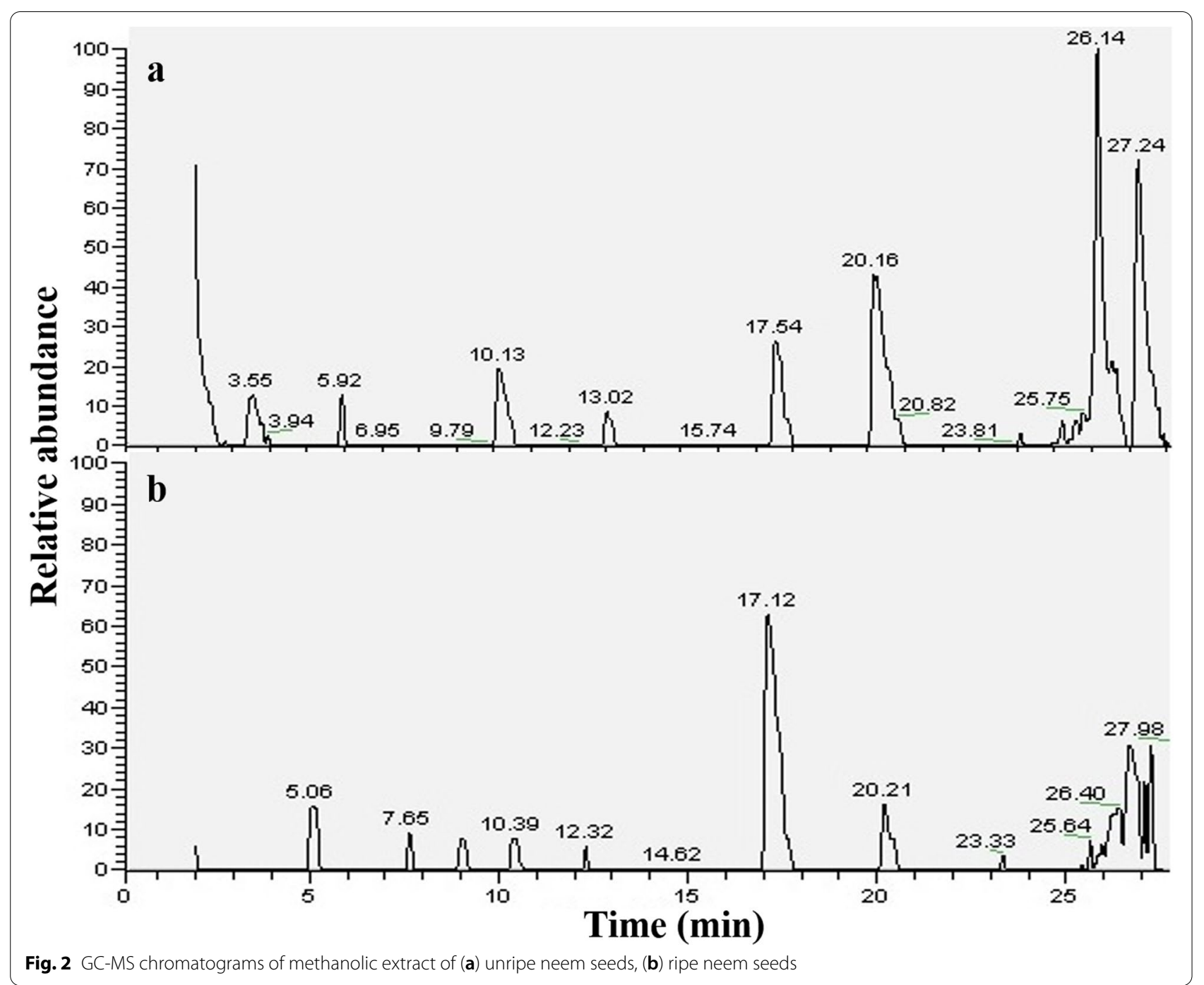

synthesis and from the GC-MS study, it has been observed that some phytochemicals, viz., 5-dihydroxy6-methyl-2,3-dihydro-4 H-pyran-4-one and 4-ethylbenzamide is present in high percentage in the ripe seed than unripe seed extract, supposed to be responsible for such effect. MIC and MBC values of vancomycin against $S$. aureus are 1.0 and $2.0 \mu \mathrm{g} / \mathrm{mL}$, respectively [87]. Whereas, MIC and MBC values of doxycycline against $V$. cholerae are 0.25 and $2 \mu \mathrm{g} / \mathrm{mL}$ respectively [89].

\section{Visualization of biofilm with fluorescence microscope}

Biofilm formed by the bacterial strains were documented with fluorescence microscopic studies after staining with DAPI [60]. Fluorescence intensities were measured as relative fluorescent unit (RFU) using online ImageJ software (ImageJ, NIH, Bethesda, Maryland, USA) and fold changes of the intensity against corresponding control system have been shown in Table S3. The control group without neem seed extract for both the bacteria produce high biofilm, whereas bacterial cells (both for $S$. aureus and $V$. cholerae) treated with unripe and ripe neem seed extracts showed moderate and low biofilm, respectively (Fig. 6). In the case of high biofilm, green fluorescent light emission was intense and for treated groups (with unripe and ripe neem seed extracts), the intensity of light emission was moderate to less.

Live and dead bacterial cells were visualized by $\mathrm{AO} /$ $\mathrm{EB}$ staining. In case of $\mathrm{AO} / \mathrm{EB}$ staining, $\mathrm{AO}$ stains the live cells while the dead bacterial cells which have lost membrane integrity get stained by EB. Representative fluorescence micrographs are shown in Fig. 7 and live/ dead bacterial cell number was counted (using ImageJ software) and fold changes against corresponding 


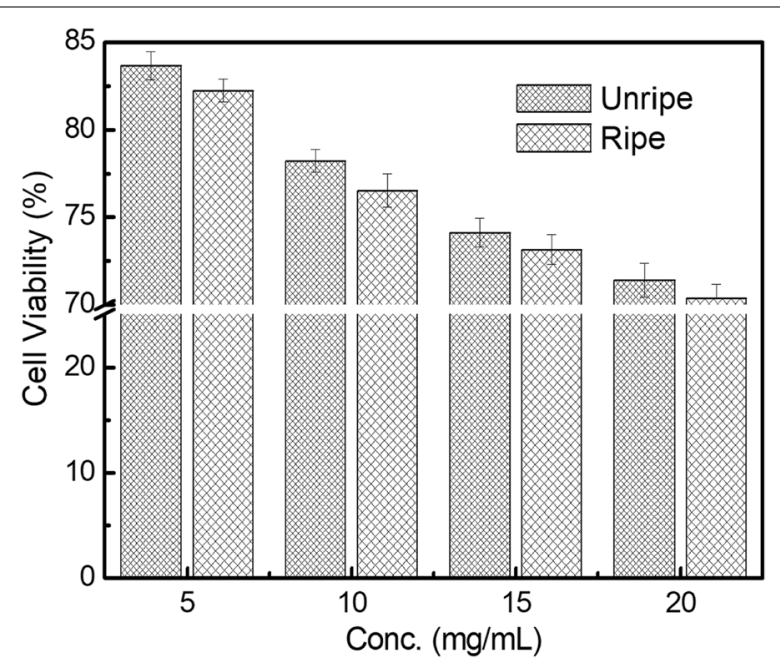

Fig. 3 Cytotoxicity study of methanolic neem seed extracts on peripheral blood lymphocytes. Data are presented as mean \pm SD

control system have been shown in Table S4. For comparative analysis of antibacterial activity, lower MIC dosage between the unripe and ripe extract $(1.2 \mathrm{mg} / \mathrm{mL}$ for $S$. aureus and $2.0 \mathrm{mg} / \mathrm{mL}$ for $V$. cholerae) were selected. The untreated cells result in maximum green fluorescence for both $S$. aureus and $V$. cholerae, where green fluorescence corresponds to live bacterial cells. Bacterial cells treated with unripe neem seed extracts exhibit moderate red fluorescence, whereas bacteria treated with ripe neem seed extracts show significantly high red fluorescence (Fig. 7). Dead bacterial cells correspond to red fluorescence as EB can cross the cell membrane of those dead bacteria.

\section{Anticancer activity}

Individually, extracts could significantly diminish the viability of MDA-MB-231 breast cancer cells for $24 \mathrm{~h}$ treatment condition and ensured 50\% inhibition concentration $\left(\mathrm{IC}_{50}\right)$ of cell proliferation. The $\mathrm{IC}_{50}$ of cell proliferation is dose-dependent. The $\mathrm{IC}_{50}$ effect of plant extract on the cell growth of MDA-MB-231 is illustrated in Fig. 8. Results revealed that unripe neem seed extract and ripe neem seed extract reflected $50 \%$ inhibitory effect at $\mathrm{IC}_{50}$ of $30 \mu \mathrm{g} / \mathrm{mL}(\mathrm{SD} \pm 2.3)$ and $10 \mu \mathrm{g} / \mathrm{mL}(\mathrm{SD} \pm 1.6)$, respectively (Fig. 8). The $\mathrm{IC}_{50}$ of gemcitabine (standard drug) could not show 50\% inhibition in concentration of cell proliferation. In Fig. 8, gemcitabine could almost $28 \%$ expressively decrease the viability of MDA-MB-231 in similar treatment condition and the concentration was found to be $125 \mu \mathrm{g} / \mathrm{mL}$. Similar observations were also obtained by Moongkarndi et al., 2004, where the proliferation of SKBR3 breast cancer cells were inhibited by $50 \%$ with $9.25 \mu \mathrm{g} / \mathrm{mL}$ crude methanolic extract of Garcinia mangostana [91]. Fig. S4 indicated reduced number

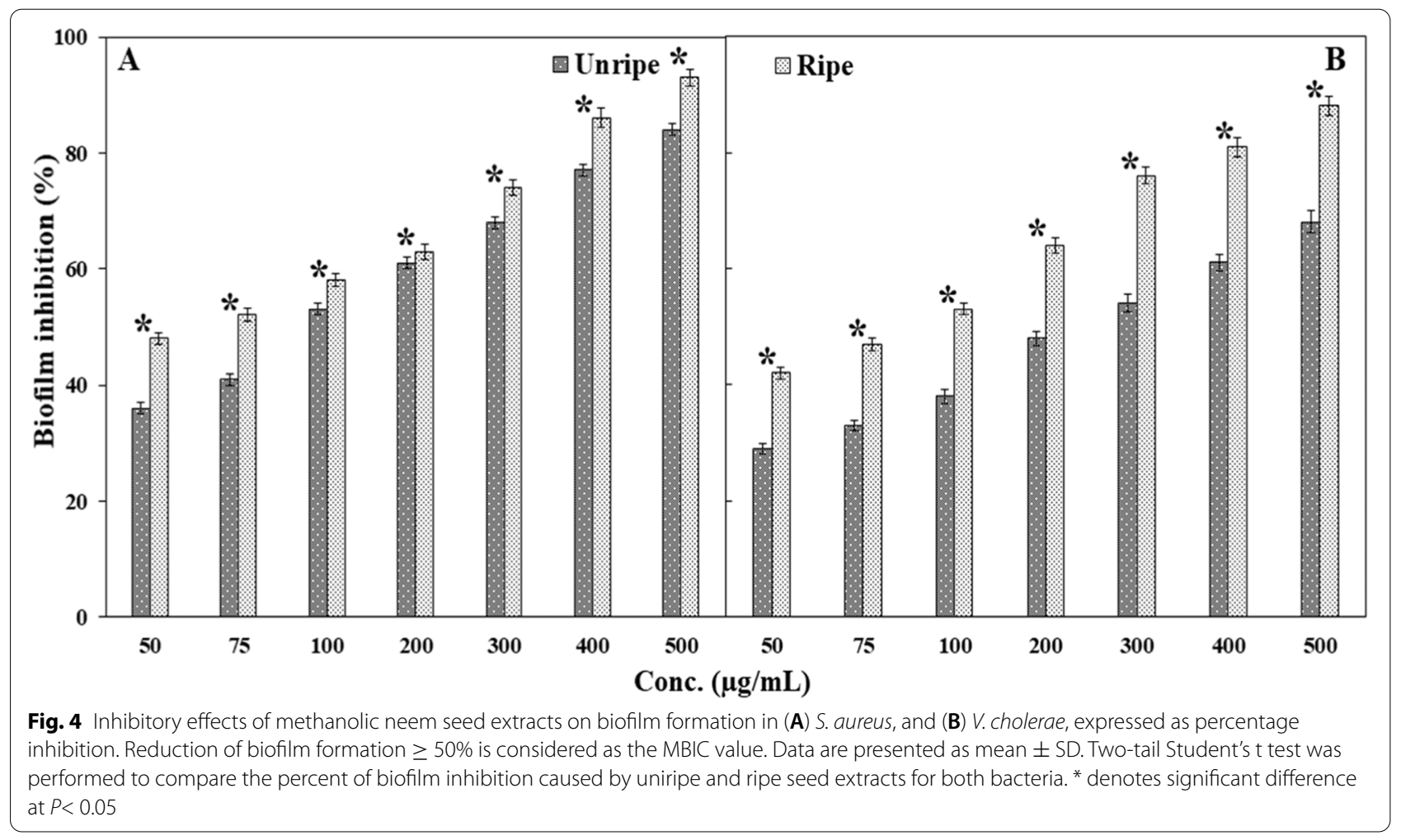




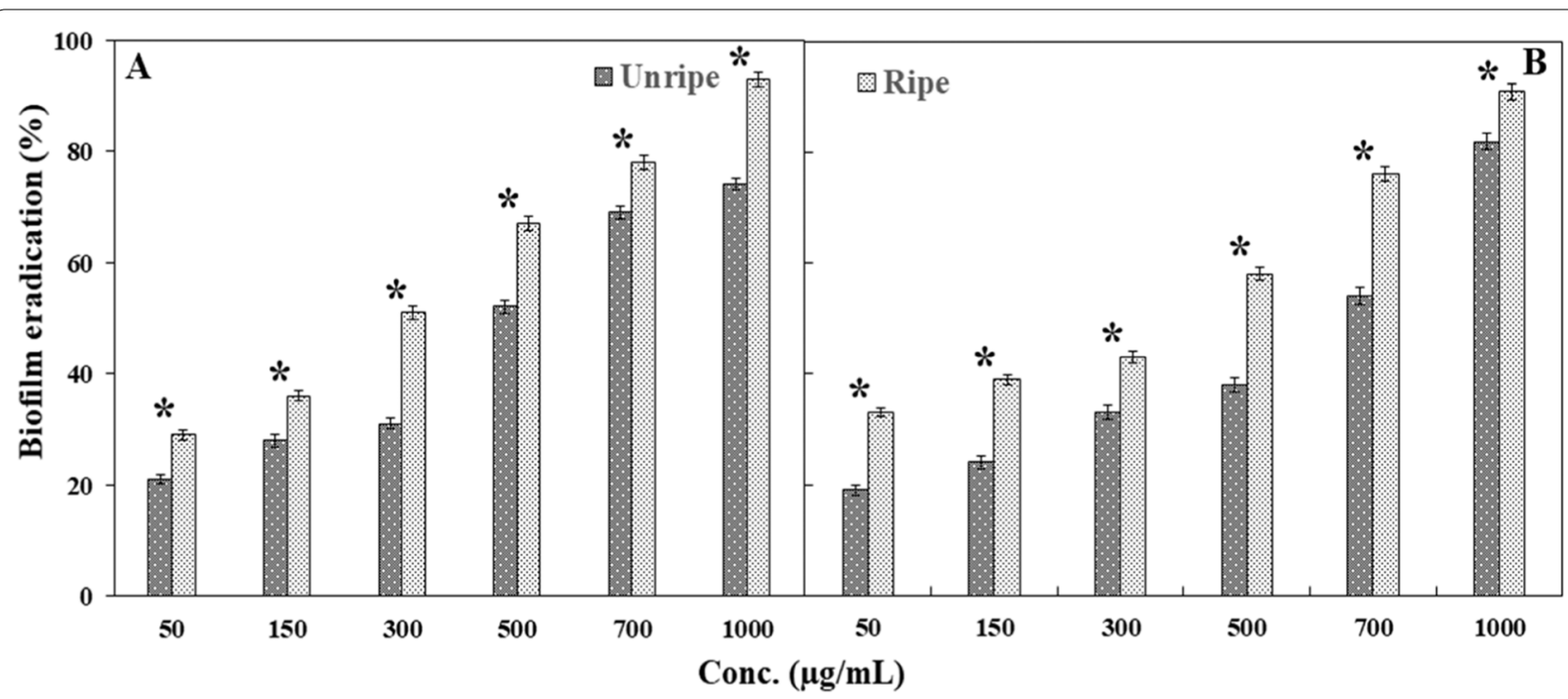

Fig. 5 Biofilm eradication activity of methanolic neem seed extracts on preformed biofilm of (A) S. aureus, (B) V. cholerae, expressed as percentage inhibition. Eradication ability of $\geq 50 \%$ of preformed biofilm is the MBEC dosage. Data are presented as mean \pm SD. Two -tail Student's $t$ test was performed to compare the percent of biofilm eradication caused by uniripe and ripe seed extracts for both bacteria. ${ }^{*}$ denotes significant difference at $P<0.05$

of MDA-MB-231 breast cancer cells as well as slight morphological alteration in the ripe neem seed extract treated group during the MTT assay. Although, no significant observable difference in cancer cell numbers was seen in between the unripe neem seed treated and gemcitabine treated groups.

\section{Immunophenotyping analysis by FACS studies}

Expression of the indispensable markers for breast cancer cell lines, CD44 and CD326 in MDA-MB-231 cells without/with the plant extract treatment were also studied through flow cytometry analysis. The cells were also treated with gemcitabine, a regular chemotherapeutic drug, as the positive control drug in similar treatment conditions where the drug was not found to function significantly in respect of untreated cells. As shown in Fig. 9, after $24 \mathrm{~h}$ of treatment with $10 \mu \mathrm{g} / \mathrm{mL}$ ripe seed extract, the level of both the marker populations decreased with respect to the untreated and positive control. In the case of unripe seed extract, both the markers were decreased from the control.

\section{Discussions}

Growing evidences of drug resistance in bacteria and several side effects of the conventional chemotherapeutic processes of cancer treatment have motivated the researchers to explore some alternative but convenient approaches for dealing of infections and cancer [92, 93]. It is known that in bacterial pathogenesis, the ability of bacterial cells to cause infection gets potentiated by conforming biofilms, based on quorum sensing (QS) signaling action. Hence, the inhibition of biofilmforming ability as well as QS, the cell-cell communication becomes a promising alternative as a controlling strategy for these healthcare issues $[8,94]$. Under such circumstances, the identification and establishment of alternative agents to antibiotics are warranted to combat bacterial infections [95]. With that intention, the present study was designed to explore the effect of methanolic extract of unripe and ripe neem seeds on biofilm formation and eradication. Exploring anticancer activity of the neem seed extracts on MDR breast cancer cells was also another significant part of this study. Thiophene derivative compounds are known to have potential remedial properties to certain biofilm-related bacterial infections [96]. In the present study, GC-MS analyses revealed the presence of 2-hexyl-tetrahydrothiophane in unripe methanolic neem seed extract, considered to be responsible for antibiofilm activity towards the target bacteria. Ripe neem seed extracts containing highest percentage of 3,5-dihydroxy-6-methyl-2,3-dihydro-4 H-pyran-4one and 4-ethylbenzamide showed significantly higher $(P<0.05)$ antibiofilm activity, as revealed through the MBIC, MBEC and fluorescence studies, than the unripe neem seed extract. 3,5-dihydroxy-6-methyl-2,3-dihydro-4 H-pyran-4-one has been reported to have potent antioxidant and antimicrobial activities [97, 98]. On the other hand, the antibacterial activity of 4-ethylbenzamide has already been described [99]. It was also found that antibiofilm activities of both the extracts were higher 
a.
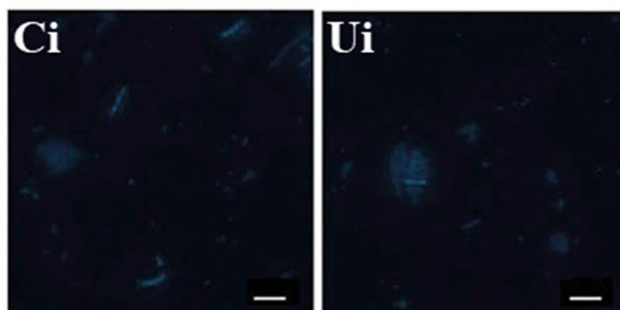

$\mathbf{R i}$

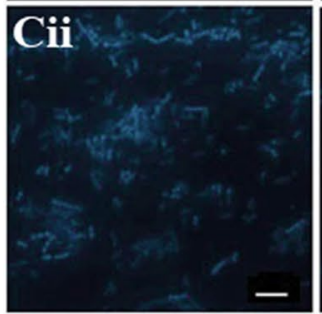

\section{Uii}

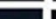
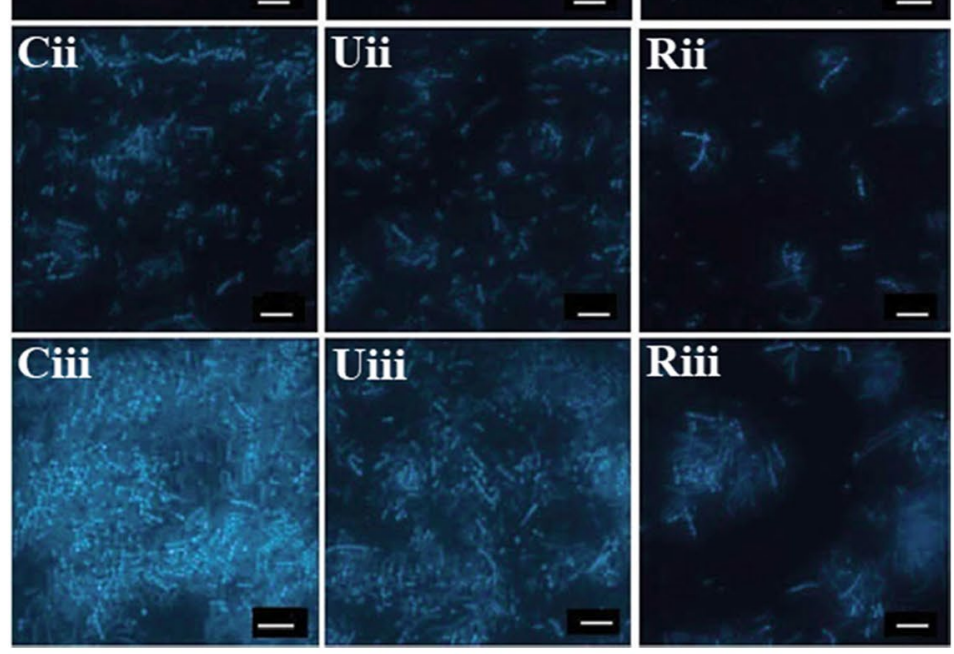

b. $\mathbf{C i}$

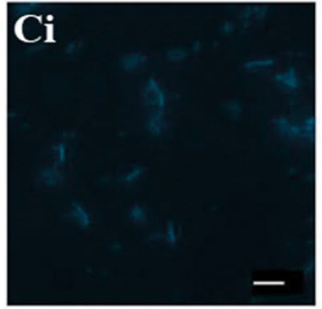

Ui
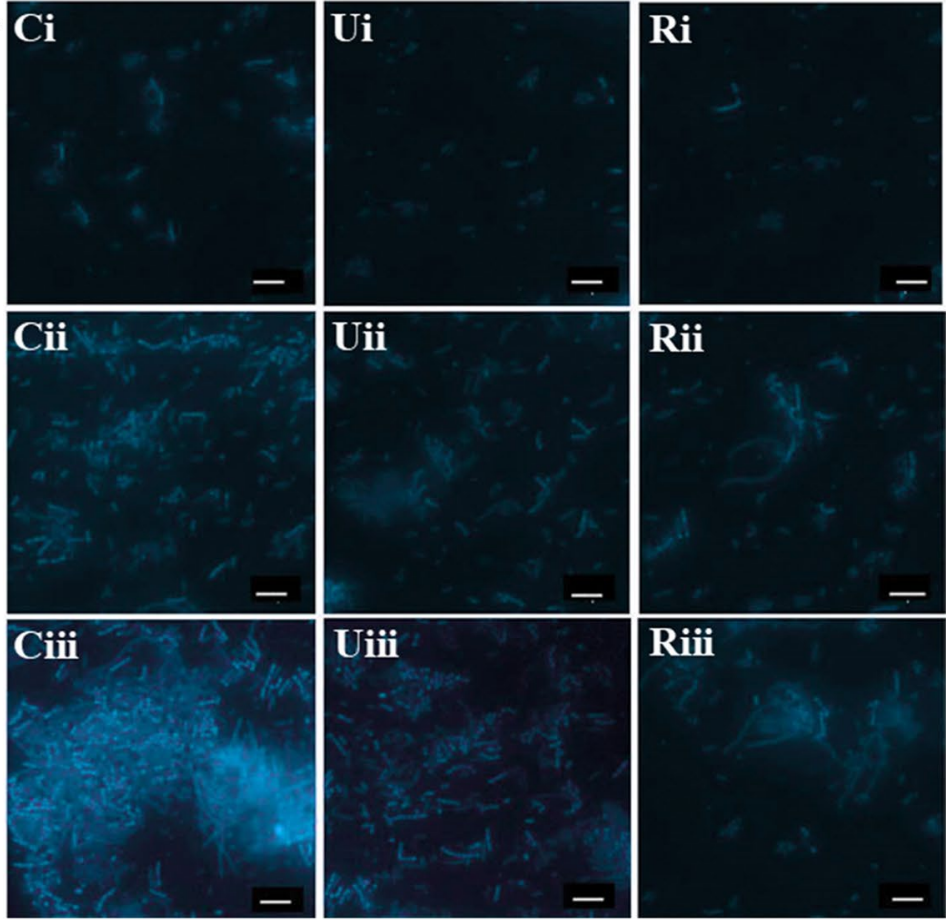

Rii

Fig. 6 Fluorescence microscopic images of DAPI stained (a) S. aureus, and (b) V. cholerae, after treatment with neem seed extracts. Vertical panels $\mathrm{Ci}$, Cii and Ciii correspond to biofilm biomass at $37^{\circ} \mathrm{C}$ for 8,16 and $24 \mathrm{~h}$, respectively; Vertical panel Ui, Uii and Uiii correspond to biofilm biomass treated with unripe neem seed extract for 8,16 and $24 \mathrm{~h}$, respectively; and, vertical panel, Ri, Rii and Riii correspond to biofilm biomass treated with ripe neem seed extract for 8,16 and $24 \mathrm{~h}$, respectively. Scale bar: $10 \mu \mathrm{m}$ 

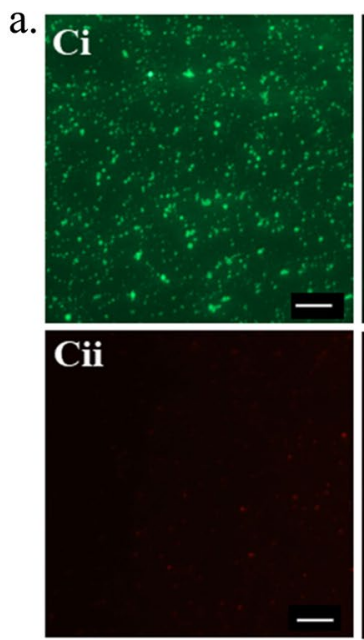

b. $\mathbf{C i}$
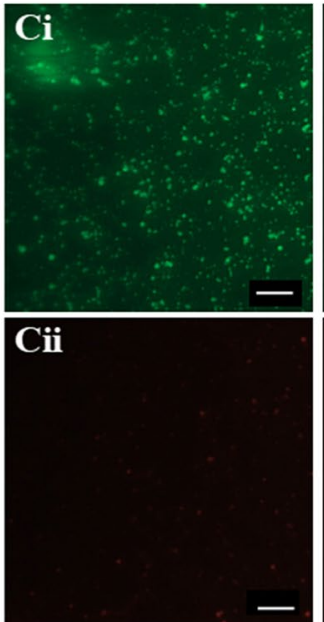
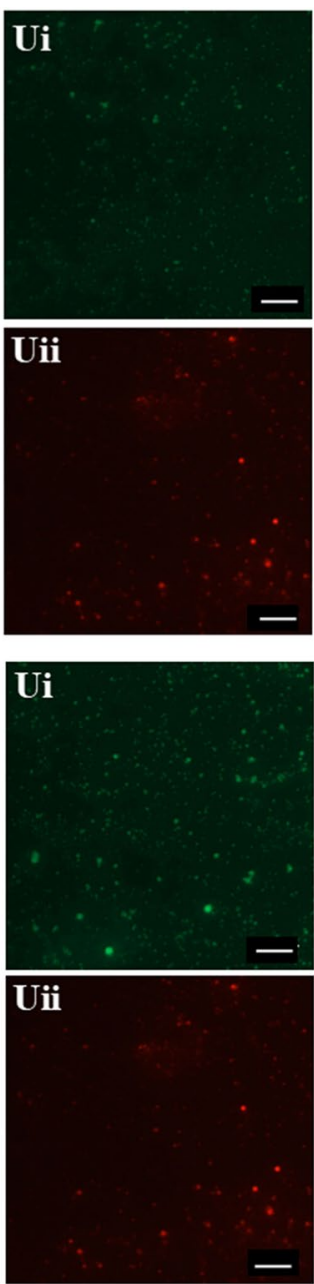
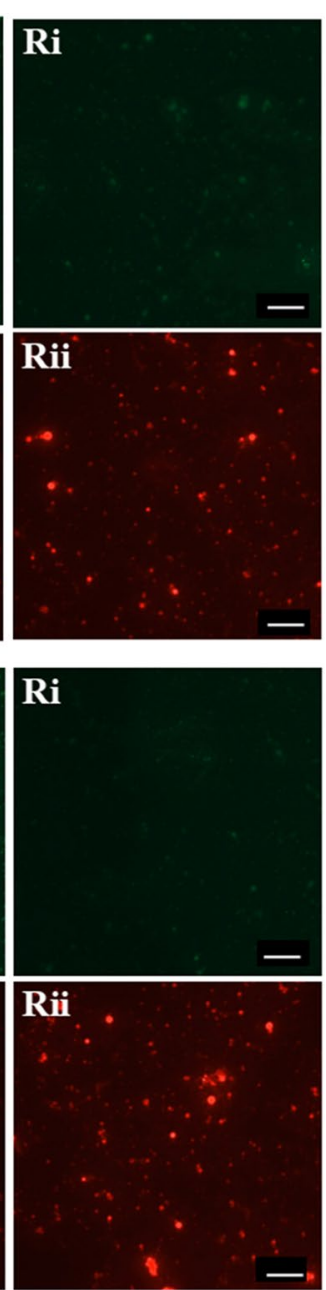

Fig. 7 Fluorescence microscopic images of bacterial cell death via AO/EB staining of (a) S. aureus, and (b) V. cholerae, after treatment with neem seed extracts. Each longitudinal panel in both figures indicates AO (Acridine Orange) and EB (Ethidium Bromide) stained live and dead bacterial cells, respectively. Live bacteria emit green fluorescence and dead bacteria emit red fluorescence. Vertical panel Ci and Cii corresponds to bacterial growth at $37^{\circ} \mathrm{C}$ for $18 \mathrm{~h}$ after $\mathrm{AO}$ and EB staining, respectively; Vertical panel Ui and Uii correspond to bacterial growth treated with unripe neem seed extract after $A O$ and EB staining, respectively; Vertical panel Ri and Rii correspond to bacterial growth treated with ripe neem seed extract after $\mathrm{AO}$ and $\mathrm{EB}$ staining, respectively. Scale bar: $20 \mu \mathrm{m}$

in the case of $S$. aureus than V. cholerae. The differential structural properties as well as biofilm regulatory properties in gram-positive and gram-negative bacteria might be the underlying causes for such observations. Besides, it may be suggested that plant extracts may play some roles in modulating cell wall synthesizing enzymes and also QS cell-cell communication and regulation during biofilm formation to induce antibiofilm activity. Moreover, 3,5-Dihydroxy-6-methyl-2,3-dihydro-4 H-pyran4-one, a derivative of kaempferol, is present in highest percentage in ripe neem seed extract. Kaempferol is clinically known to possess anticancer, antimicrobial and antioxidant activities [100, 101]. Kaempferol derivatives and its synergistic action along with other compounds present in the seed extracts, is considered to be responsible for possessing significantly higher antibiofilm as well as anticancer activity in methanolic ripe neem seed extracts than unripe neem seed extract. MIC and MBC results also indicate that ripe neem seed extracts possess greater antibacterial activity than unripe extracts against both tested gram-positive (S. aureus) and gram-negative (V. cholerae) bacteria. In this context it may also be considered that some antibiotics exhibit antibiofilm activities, but report reveals that conventional antibiotics are not prudent enough against bacterial biofilm [102]. Also, combination strategies, involving different antimicrobial peptides (AMPs) are being used along with different conventional antibiotics [102]. Besides, numerous 


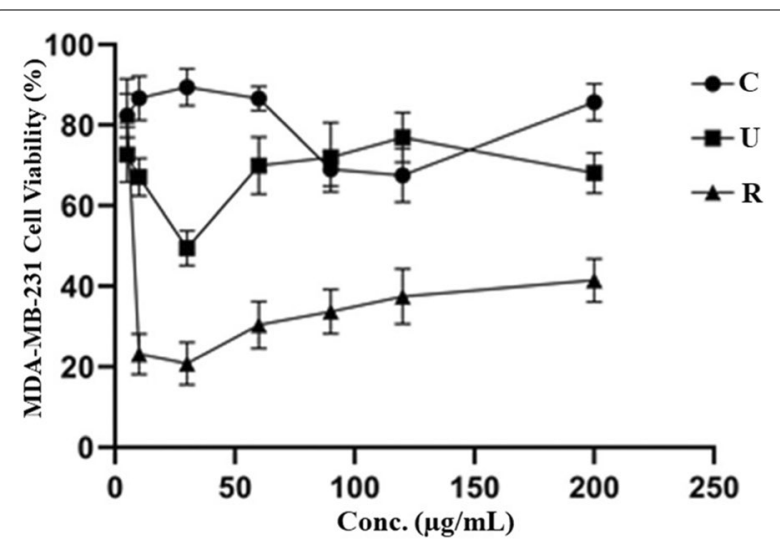

Fig. 8 Evaluation of cell viability of multidrug-resistant breast cancer cell MDA-MB-231 treated with control drug gemcitabine (C), unripe neem seed $(U)$ and ripe neem seed $(R)$ extract by MTT assay. I $C_{50}$ dosage against selected cancer cells for control drug Gemcitabine (C) was found to be $200 \mu \mathrm{g} / \mathrm{mL}$, whereas the same for unripe (U) and ripe (R) seed extracts were $30 \mu \mathrm{g} / \mathrm{mL}$ and $10 \mu \mathrm{g} / \mathrm{mL}$, respectively

phytochemicals are being used as antimicrobial and antibiofilm agents. Hence depending on several reports, it appears that effective therapeutic outcome along with lesser side effects and lower propensity for resistance development of the phytochemicals validate their usefulness as an alternative to antibiotics and other chemotherapeutics $[103,104]$.
MTT analysis showed the reduced viability of the breast cancer cell line, whereas, FACS study emphasizes that both the CD44 and CD326 populations of the breast cancer cells have been significantly decreased. CD44 and CD326 are cell surface markers. The population of these markers significantly increased during the cancer prognosis and, induces cell signalling, proliferation, differentiation and migration of the cancer cells $[105,106]$. Here, Ripe seed extract possessed significantly greater killing potency against the cancer cell line than unripe extract. Several studies on 3,5-dihydroxy-6-methyl-2,3-dihydro-4 H-pyran-4-one showed its antimicrobial and anti-proliferative activity [98], and 4-ethylbenzamide, derivatives of 4-thiazolidinone conferred their anticancer potency [107]. It was also observed that ripe seed extract has superior anticancer activity than that found with gemcitabine and unripe seed extract. Unripe seed extract could reduce the population of cancer cells similar to the magnitude of gemcitabine-based inhibition. It may be suggested from the present study that neem seed extracts have some role in the inhibition of cancer cell proliferation and differentiation as well as induction of apoptosis process in cancer cells. Further studies are warranted for identification and characterization of the particular phytochemical responsible for the antibiofilm and anticancer activities. It is also necessary to pinpoint the component transformed during ripening of the seeds, considered to

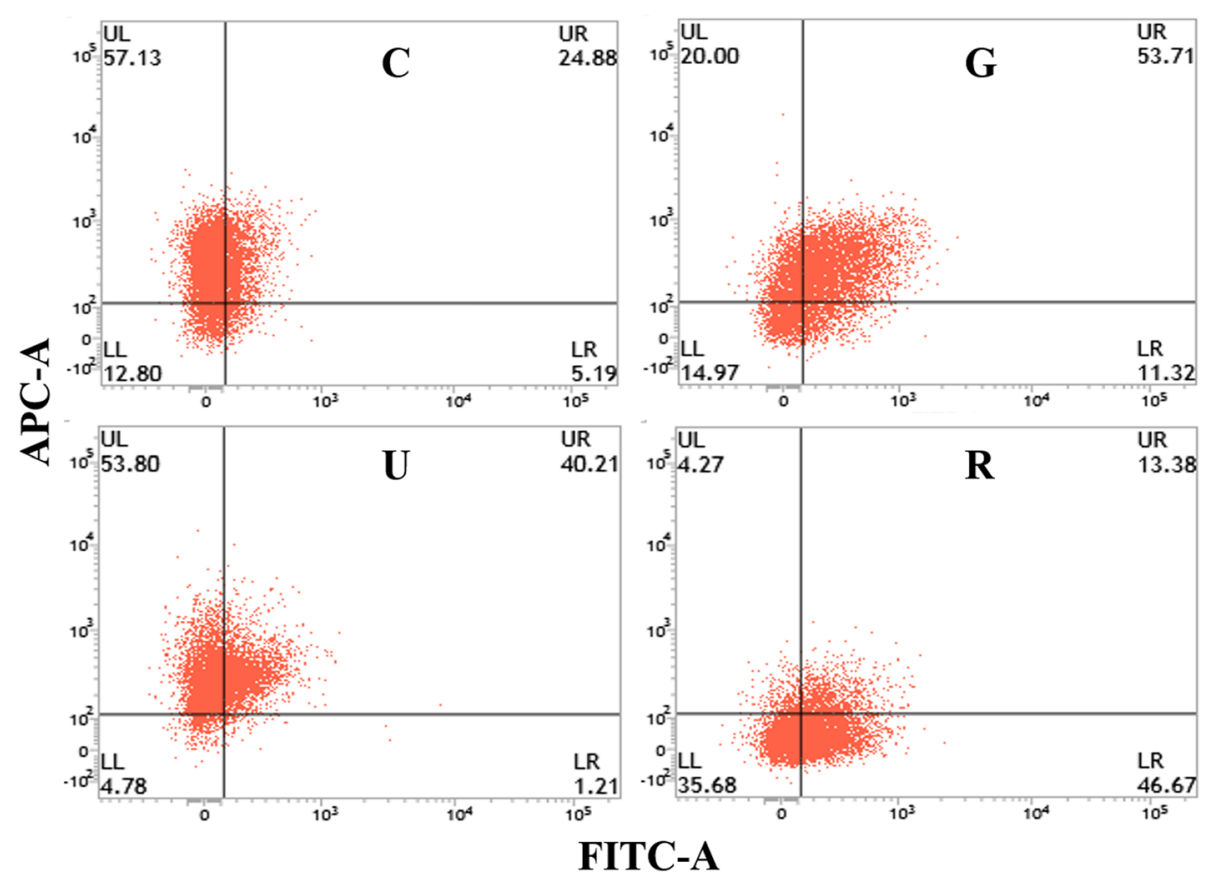

Fig. 9 The fate of MDA-MB-231 CD44 positive (FITC conjugated) and EpCAM positive (APC conjugated) breast cancer stem cell line as, C: cell line without any treatment, G: cell line treated with Gemcitabine, U: cell line treated with unripe neem seed extract, and R: cell line treated with ripe neem seed extract 
be responsible for the enhanced antibiofilm and anticancer activities.

Though the effective concentrations of the extracts were relatively higher than the conventional antibiotics, it should also be considered that these extracts contain several components and the effect of each of the components are needed to be investigated. The next approach will be to identify the individual components responsible for such effects along with tracking the exact pathway by which they exert their action. When all these factors are taken into account, it will certainly be helpful in the development of some new potent alternatives to the conventional antibiotics. Besides, easy availability, low cost, fewer side effects and long history of use in folk medicine for curing several infections and disease, are considered to make plant extracts as good resource for investigations.

\section{Conclusions}

Antibiofilm studies of neem seed extracts against $S$. aureus and $V$. cholerae show that the methanolic extracts of neem seeds are potentially effective against the formation and eradication of bacterial biofilm. Above a certain concentration, both the unripe and ripe seed extracts are capable to cease bacterial growth. Interestingly, these phytoextracts also possess potential anticancer activity on MDA-MB-231 breast cancer cell line. Methanolic extracts of ripe neem seed have significantly greater efficiency than the unripe neem seed. It could be due to the secondary metabolites of neem seed during the process of ripening. These key findings indicate that both unripe and ripe seed extracts can be beneficial for anti-virulence strategies through anti-biofilm potential against numerous pathogenic bacteria. Simultaneously the ability of these extracts to destroy cancer cells opens a new dimension in cancer therapeutics. The present results clearly indicate that the methanolic extracts of both unripe and ripe neem seeds can safely be used for acting as antibiofilm and anticancer agents in modern phytomedicine. However, ripe seed extract showed higher antibiofilm, antibacterial and anticancer activities. Furthermore, identification and exploration of the active compounds behind such activities are needed.

\footnotetext{
Abbreviations

MRSA: Methicillin-resistant staphylococcus aureus; RPMI: Roswell park memorial institute medium; PBS: Phosphate-buffered saline; DMSO: Dimethyl sulfoxide; MTT: 3-(4,5-Dimethylthiazol-2-yl)-2,5-diphenyl tetrazolium bromide; FTIR: Fourier transform infrared spectroscopy; MBIC: Minimum biofilm inhibitory concentration; MBEC: Minimum biofilm eradication concentration; MIC: Minimum inhibitory concentration; MBC: Minimum bactericidal concentration; DAPI: 4,6- Diamidino-2-phenylindole; DMEM: Dulbecco's modified eagle medium; FACS: Fluorescence activated cell sorting; CLSI: Clinical \& laboratory standards institute.
}

\section{Supplementary Information}

The online version contains supplementary material available at https://doi. org/10.1186/s12906-022-03513-4.

\section{Additional file 1.}

\section{Acknowledgements}

Authors gratefully acknowledge Dr. Debabrata Maity, Assistant Professor in Botany, University of Calcutta, West Bengal, India for identification as well as authentication of the plant. The University Scientific Instrument Centre (USIC), Vidyasagar University is also acknowledged in performing the fluorescence microscopy and FTIR studies.

\section{Authors' contributions}

KCG, AKP and CG planned and designed the work, KCG, TM, DJ and MK prepared the extracts as well as studied the anti-biofilm and anti- bacterial activities, AD studied the MTT assay, SKN, RB, SP and SC studied the anti-cancer activities, KCG, MB, MK, AKP and AP studied and analyzed the FTIR and GC-MS data. KCG, TM, SKN, MK, PR, RB, AKP and CG prepared the manuscript. The author(s) read and approved the final manuscript.

\section{Funding}

KCG, TM and MK gratefully acknowledge the University Grants Commission (UGC), India, for funding research fellowships. AKP sincerely acknowledges the Department of Biotechnology, Govt. of India (Project Number BT/PR3802/ BRB/10/981/2011) for financial support.

\section{Availability of data and materials}

All data generated or analyzed during this study are included in this article and its supplementary information files. Additionally, this study does not have any mandate data.

\section{Declarations}

Ethics approval and consent to participate

Experimental protocols involving blood samples drawn from human subjects were approved by Institutional Ethics Committee of Vidyasagar University, West Bengal, India. Blood samples were collected from healthy adult human subjects with their informed consent and for the study, all the methods were performed in accordance with the relevant guidelines and regulations.

\section{Consent for publication}

Not applicable.

\section{Competing interests}

The authors declare that they have no competing interests.

\section{Author details}

${ }^{1}$ Department of Human Physiology, Vidyasagar University, Midnapore 721102 , West Bengal, India. ${ }^{2}$ Department of Chemistry, Vidyasagar University, Midnapore 721102, West Bengal, India. ${ }^{3}$ Department of Molecular Biology, Netaji Subhas Chandra Bose Cancer Research Institute, 3081 Nayabad, Kolkata 700094, West Bengal, India. ${ }^{4}$ Department of Biophysics, Bose Institute, P-1/12 CIT Road, Scheme VIIM, Kankurgachi, Kolkata 700054, West Bengal, India. ${ }^{5}$ Chemistry of Interfaces Group, Luleå University of Technology, SE97187 Luleå, Sweden. 'Sadhu Ram Chand Murmu University of Jhargram, Jhargram 721507, West Bengal, India.

Received: 31 July 2021 Accepted: 7 January 2022

Published online: 14 February 2022

\footnotetext{
References

1. Campoccia D, Mirzaei R, Montanaro L, Arciola CR. Hijacking of immune defences by biofilms: a multifront strategy. Biofouling. 2019, 35(10):1055-1074.
} 
2. Smith RA, M'ikanatha NM, Read AF. Antibiotic resistance: a primer and call to action. Health commun. 2015, 30(3):309-314.

3. Malaikozhundan B, Vaseeharan B, Vijayakumar S, Sudhakaran R, Gobi $\mathrm{N}$, Shanthini G. Antibacterial and antibiofilm assessment of Momordica charantia fruit extract coated silver nanoparticle. Biocatal Agric Biotechnol. 2016,8:189-196.

4. Khaled JM, Alyahya SA, Kanisha CC, Alharbi NS, Kadaikunnan S, Ramachandran G, Alanzi KF, Rajivgandhi G, Vimala RT, Manoharan N. Anti-biofilm activity of LC-MS based Solanum nigrum essential oils against multi drug resistant biofilm forming P. mirabilis. Saudi J Biol Sci. 2021, 28(1):302-309.

5. Bassetti M, Righi E. Multidrug-resistant bacteria: what is the threat?. Hematology Am Soc Hematol Educ Program. 2013,1:428-432.

6. Arciola CR, Campoccia D, Montanaro L. Implant infections: adhesion, biofilm formation and immune evasion. Nat Rev Microbiol. 2018,16(7):397-409.

7. Malaikozhundan B, Vijayakumar S, Vaseeharan B, Jenifer AA, Chitra P, Prabhu NM, Kannapiran E. Two potential uses for silver nanoparticles coated with Solanum nigrum unripe fruit extract: biofilm inhibition and photodegradation of dye effluent. Microb Pathog. 2017, 1(111):316-324

8. Wang $S$, George D, Purych D, Patrick D. Antibiotic resistance: a global threat to public health. BCMJ. 2014,6:295-296.

9. Xin LY, Min TH, Zin PN, Pulingam T, Appaturi JN, Parumasivam T. Antibacterial potential of Malaysian ethnomedicinal plants against methicillin-susceptible Staphylococcus aureus (MSSA) and methicillin-resistant Staphylococcus aureus (MRSA). Saudi J Biol Sci. 2021, 28(10):5884-5889.

10. Parsek MR, Singh PK. Bacterial biofilms: an emerging link to disease pathogenesis. Ann Rev Microbiol. 2003,57(1):677-701.

11. Kiedrowski MR, Horswill AR. New approaches for treating staphylococcal biofilm infections. Ann NY Acad Sci. 2011, 1241(1):104-121.

12. Barrett $L$, Atkins B. The clinical presentation of prosthetic joint infection. J Antimicrob Chemother. 2014,69:25-27.

13. Carroll PA, Tashima KT, Rogers MB, DiRita VJ, Calderwood SB. Phase variation in tcpH modulates expression of the ToxR regulon in Vibrio cholerae. Mol Microbiol. 1997, 25(6):1099-1111.

14. Ramirez DA, Saka HA, Nores R. Detection of Vibrio cholerae aDNA in human burials from the fifth cholera pandemic in Argentina (1886-1887 AD). Int J Paleopathol. 2021, 32:74-79.

15. Shankar U, Jain N, Majee P, Kodgire P, Sharma TK, Kumar A. Exploring computational and biophysical tools to study the presence of G-quadruplex structures: a promising therapeutic solution for drug-resistant Vibrio cholerae. Front Genet. 2020, 935-950.

16. Aurin SA, Chowdhury SP, Abony M, Rifa J, Banik A, Fatema AN, Ghurnee $\mathrm{O}$, Ahmed Z. Characterization of Multi-Drug Resistant Gram-Negative Bacteria Present in Fresh Leafy \& Salad Vegetables in Dhaka, Bangladesh. EJERS, 2020, 5(11):1322-1327.

17. Jamal M, Ahmad W, Andleeb S, Jalil F, Imran M, Nawaz MA, Hussain T, Ali M, Rafiq M, Kamil MA. Bacterial biofilm and associated infections. J Chin Med Assoc. 2018, 81(1):7-11.

18. Fernández-Delgado M, Giarrizzo JG, García-Amado MA, Contreras M Salazar V, Barton H, Suárez P. Evidence of Helicobacter spp. in freshwaters from Roraima Tepui, Guayana Shield, South America. Antonie van Leeuwenhoek. 2016, 109(4):529-542.

19. Husain FM, Perveen K, Qais FA, Ahmad I, Alfarhan AH, El-Sheikh MA. Naringin inhibits the biofilms of metallo- $\beta$-lactamases (M $\beta L$ s) producing Pseudomonas species isolated from camel meat. Saudi J Biol Sci. 2021, 28(1):333-341.

20. Ohlsen K, Koller KP, Hacker J. Analysis of expression of the alpha-toxin gene (hla) of Staphylococcus aureus by using a chromosomally encoded hla:: lacZ gene fusion. Infect Immun. 1997, 65(9):3606-3614.

21. Chatterjee T, Saha T, Sarkar P, Hoque KM, Chatterjee BK, Chakrabarti P. The gold nanoparticle reduces Vibrio cholerae pathogenesis by inhibition of biofilm formation and disruption of the production and structure of cholera toxin. Colloids Surf B: Biointerfaces. 2021, 204:111811.

22. Orgad O, Oren $Y$, Walker SL, Herzberg M. The role of alginate in Pseudomonas aeruginosa EPS adherence, viscoelastic properties and cell attachment. Biofouling. 2011, 27(7):787-98.

23. Haiyan G, Lijuan H, Shaoyu L, Chen Z, Ashraf MA. Antimicrobial, antibiofilm and antitumor activities of essential oil of Agastache rugosa from Xinjiang, China. Saudi J Biol Sci. 2016, 23(4):524-530.
24. Stewart PS. Diffusion in biofilms. J Bacteriol. 2003,185(5):1485-1491.

25. Zhang N, Wang D, Liu Y, Li S, Shen Q, Zhang R. Effects of different plant root exudates and their organic acid components on chemotaxis, biofilm formation and colonization by beneficial rhizosphere-associated bacterial strains. Plant soil. 2014,374(1):689-700.

26. Torre LA, Bray F, Siegel RL, Ferlay J, Lortet-Tieulent J, Jemal A. Global cancer statistics, 2012. CA: Cancer J Clin. 2015,65(2):87-108.

27. Del Arco A, Tortajada B, de la Torre J, Olalla J, Prada JL, Fernández F, Rivas F, García-Alegría J, Faus V, Montiel N. The impact of an antimicrobial stewardship programme on the use of antimicrobials and the evolution of drug resistance. Eur. J. Clin Microbiol Infect Dis. 2015, 34(2):247-251.

28. Shackleton M, Quintana E, Fearon ER, Morrison SJ. Heterogeneity in cancer: cancer stem cells versus clonal evolution. Cell. 2009,138(5):822-829.

29. Jemal A, Bray F, Center MM, Ferlay J, Ward E, Forman D. Global cancer statistics. CA: Cancer J Clin. 2011, 61 (2):69-90.

30. Siegel RL, Miller KD, Goding Sauer A, Fedewa SA, Butterly LF, Anderson JC, Cercek A, Smith RA, Jemal A. Colorectal cancer statistics, 2020. CA: Cancer J Clin. 2020, 70(3):145-164.

31. Wild C. World cancer report 2014. Wild CP, Stewart BW, editors. Geneva, Switzerland:WHO. 2014: 482-494

32. Siegel RL, Miller KD, Fedewa SA, Ahnen DJ, Meester RG, Barzi A, Jemal A. Colorectal cancer statistics, 2017. CA: Cancer J Clin. 2017, 67(3):177-193.

33. Baskar R, Dai J, Wenlong N, Yeo R, Yeoh KW. Biological response of cancer cells to radiation treatment. Front Mol Biosci. 2014,1:24-32.

34. Asif M. Quorum sensing inhibitors: Current progress of the natural antimicrobials. J Chem Rev. 2021, 3(1):20-39.

35. Iabal J, Abbasi BA, Batool R, Mahmood T, Ali B, Khalil AT, Kanwal S, Shah SA, Ahmad R. Potential phytocompounds for developing breast cancer therapeutics: nature's healing touch. Eur J Pharmacol. 2018,827:125-148.

36. Kuang W, Hu W, Ren H, Shao Y, Liu B. Plant derived coumestrol phytochemical targets human skin carcinoma cells by inducing mitochondrial-mediated apoptosis, cell cycle arrest, inhibition of cell migration and invasion and modulation of m-TOR/PI3K/AKT signalling pathway Saudi J Biol Sci. 2021, 28(5):2739-2746.

37. Pederson DB, Dong Y, Blue LB, Smith SV, Cao M. Water-soluble cranberry extract inhibits Vibrio cholerae biofilm formation possibly through modulating the second messenger 3', 5'-Cyclic diguanylate level. Plos one. 2018, 13(11):1-9.

38. Malaikozhundan $B$, Vinodhini J, Kalanjiam MA, Vinotha V, Palanisamy S, Vijayakumar S, Vaseeharan B, Mariyappan A. High synergistic antibacterial, antibiofilm, antidiabetic and antimetabolic activity of Withania somnifera leaf extract-assisted zinc oxide nanoparticle. Bioprocess Biosyst Eng. 2020, 43(9):1533-1547.

39. Malaikozhundan B, Vaseeharan B, Vijayakumar S, Pandiselvi K, Kalanjiam MA, Murugan K, Benelli G. Biological therapeutics of Pongamia pinnata coated zinc oxide nanoparticles against clinically important pathogenic bacteria, fungi and MCF-7 breast cancer cells. Microb Pathog. 2017, 104:268-277.

40. Subramani R, Narayanasamy M, Feussner KD. Plant-derived antimicrobials to fight against multi-drug-resistant human pathogens. 3 Biotech. 2017, 7(3):1-5.

41. Pandey AK, Kumar S. Perspective on plant products as antimicrobial agents: A review. Pharmacologia. 2013, 4(7):469-480.

42. Ibrahim N, Kebede A. In vitro antibacterial activities of methanol and aqueous leave extracts of selected medicinal plants against human pathogenic bacteria. Saudi J Biol Sci. 2020,27(9):2261-2268.

43. Jana D, Guchhait KC, Ballav S, Panda AK, Ghosh C. Traditional Herbal Medicine Practiced in Plateau-Fringe and Rarh Districts of West Bengal, India. Evidence Based Validation of Traditional Medicines. Springer. 2021:1019-1089.

44. Paul R, Prasad M, Sah NK. Anticancer biology of Azadirachta indica L (neem): a mini review. Cancer Biol Ther. 2011, 12(6):467-476.

45. Gupta S, Kataria M, Gupta PK, Murganandan S, Yashroy RC. Protective role of extracts of neem seeds in diabetes caused by streptozotocin in rats. J Ethnopharmacol. 2004, 90:185-189.

46. Karmakar A, Dua P, Ghosh C. Biochemical and molecular analysis of Staphylococcus aureus clinical isolates from hospitalized patients. Can J Infect Dis Med Microbiol. 2016,1-7. 
47. Dua P, Karmakar A, Ghosh C. Virulence gene profiles, biofilm formation, and antimicrobial resistance of Vibrio cholerae non-O1/non-O139 bacteria isolated from West Bengal, India. Heliyon. 2018, 4(12):1-17.

48. Truong DH, Nguyen DH, Ta NT, Bui AV, Do TH, Nguyen HC. Evaluation of the use of different solvents for phytochemical constituents, antioxidants, and in vitro anti-inflammatory activities of Severinia buxifolia. J Food Qual. 2019, 1-9.

49. Rangasamy O, Raoelison G, Rakotoniriana FE, Cheuk K, Urverg-Ratsimamanga S, Quetin-Leclercq J, Gurib-Fakim A, Subratty AH. Screening for anti-infective properties of several medicinal plants of the Mauritians flora. J Ethnopharmacol. 2007, 109(2):331-337.

50. Kumar SS, Manoj P, Giridhar P. Fourier transform infrared spectroscopy (FTIR) analysis, chlorophyll content and antioxidant properties of native and defatted foliage of green leafy vegetables. J Food Sci Technol. 2015, 52(12):8131-8139.

51. Ayaz M, Junaid M, Ullah F, Sadiq A, Shahid M, Ahmad W, Ullah I, Ahmad A, Syed NI. GC-MS analysis and gastroprotective evaluations of crude extracts, isolated saponins, and essential oil from Polygonum hydropiper L. Front Chem. 2017, 5:58. https://doi.org/10.3389/fchem.2017.00058

52. Bigelow JC, Giddings JC, Nabeshima Y, Tsuruta T, Kataoka K, Okano T, Yui N, Sakurai Y. Separation of B and T lymphocytes by a hybrid fieldflow fractionation/adhesion chromatography technique. J Immunol Method. 1989, 117(2):289-293.

53. Weichert H, Blechschmidt I, Schröder S, Ambrosius H. The MTT-assay as a rapid test for cell proliferation and cell killing: application to human peripheral blood lymphocytes (PBL). Allergie und Immunol. 1991,37:139-144.

54. Mathur T, Singhal S, Khan S, Upadhyay DJ, Fatma T, Rattan A. Detection of biofilm formation among the clinical isolates of staphylococci: an evaluation of three different screening methods. Indian J Med Microbiol. 2006,24(1):25-29.

55. Sandasi M, Leonard CM, Viljoen AM. The effect of five common essential oil components on Listeria monocytogenes biofilms. Food Control. 2008, 19(11):1070-1075.

56. Biswas S, Mukherjee P, Manna T, Dutta K, Guchhait KC, Karmakar A, Karmakar M, Dua P, Panda AK, Ghosh C. Quorum sensing autoinducer (s) and flagellum independently mediate EPS signaling in Vibrio cholerae through LuxO-independent mechanism. Microb Ecol. 2019,77(3):616-630

57. Watnick PI, Kolter R. Steps in the development of a Vibrio cholerae El Tor biofilm. Mol Microbiol. 1999, 34(3):586-595.

58. Taylor PC, Schoenknecht FD, Sherris JC, Linner EC. Determination of minimum bactericidal concentrations of oxacillin for Staphylococcus aureus: influence and significance of technical factors. Antimicrob Agent Chemother. 1983, 23(1):142-150.

59. Chan MM. Antimicrobial effect of resveratrol on dermatophytes and bacterial pathogens of the skin. Biochem Pharmacol. 2002, 63(2):99-104.

60. Peele KA, Ch VR, Kodali VP. Emulsifying activity of a biosurfactant produced by a marine bacterium. 3 Biotech. 2016, 6(2):1-6.

61. Khan I, Bahuguna A, Kumar P, Bajpai VK, Kang SC. Antimicrobial potential of carvacrol against uropathogenic Escherichia coli via membrane disruption, depolarization, and reactive oxygen species generation. Front Microbiol. 2017,8:2421.

62. Mertens-Talcott SU, Chintharlapalli S, Li X, Safe S. The oncogenic microRNA-27a targets genes that regulate specificity protein transcription factors and the G2-M checkpoint in MDA-MB-231 breast cancer cells. Cancer res. 2007, 67(22):11001-11011.

63. Liu T, Zhou L, Li D, Andl T, Zhang Y. Cancer-associated fibroblasts build and secure the tumor microenvironment. Front Cell Dev Biol. 2019, 7:60-73.

64. Jiao X, Rizvanov AA, Cristofanilli M, Miftakhova RR, Pestell RG. Breast cancer stem cell isolation. In Breast Cancer. Humana Press, New York, NY. 2016,121-135

65. Mosmann T. Rapid colorimetric assay for cellular growth and survival: application to proliferation and cytotoxicity assays. J Immunol. Method. 1983,65:55-63.

66. Yamaue H, Tanimura H, Nakamori M, Noguchi K, Iwahashi M, Tani M, Hotta T, Murakami K, Ishimoto K. Clinical evaluation of chemosensitivity testing for patients with colorectal cancer using MTT assay. Dis Colon Rectum. 1996, 39(4):416-422.
67. Wu K, Jiao X, Li Z, Katiyar S, Casimiro MC, Yang W, Zhang Q, Willmarth NE, Chepelev I, Crosariol M, Wei Z. Cell fate determination factor Dachshund reprograms breast cancer stem cell function. J Biol Chem. 2011, 286(3):2132-2142

68. Prahas D, Kartika Y, Indraswati N, Ismadji SJ. Activated carbon from jackfruit peel waste by $\mathrm{H} 3 \mathrm{PO} 4$ chemical activation: Pore structure and surface chemistry characterization. Chem Eng. 2008, 140:32-42.

69. Ahmad AA, Hameed BH. Reduction of COD and color of dyeing effluent from a cotton textile mill by adsorption onto bamboo-based activated carbon. J Haz Mat. 2009, 172:1538-1543.

70. Dubey S, Kashyap P. Azadirachta indica: A plant with versatile potential. RGUHS J Pharm Sci. 2014, 4(2):39-46.

71. Piscopo E, Diurno MV, Cataldi MT, Scala G, Aliberti F. Biological activity of 4-hydroxyisophthalic acid derivatives. Hydrazones with antimicrobial activity. Boll Soc Ital Biol Sper. 1984, 60(6):1169-1175.

72. Isloor AM, Kalluraya B, Pai KS. Synthesis, characterization and biological activities of some new benzo [b] thiophene derivatives. Eur J Med Chem. 2010,45(2):825-830.

73. Mishra R, Jha KK, Kumar S, Tomer I. Synthesis, properties and biological activity of thiophene: A review. Der Pharma Chemica. 2011, 3(4):38-54

74. Hwang IG, Kim HY, Woo KS, Lee SH, Lee J, Jeong HS. Isolation and identification of the antioxidant DDMP from heated pear (Pyrus pyrifolia Nakai). Prev Nutri Food Sci. 2013, 18(1):76-79.

75. Asif M. Pharmacological potential of benzamide analogues and their uses in medicinal chemistry. Mod Chem Appl. 2016, 4:194-196.

76. Prasad S, Radhakrishna V, Ravi TK. Synthesis, spectroscopic and antibacterial studies of some schiff bases of 4-(4-bromophenyl)6-(4-chlorophenyl)-2-aminopyrimidine. Arab J Chem. 2019, 12(8):3943-3947.

77. Bassyouni FA, Tawfik HA, Hamed AR, Soltan MM, ElHefnawi M, EIRashedy AA, Moharam ME, Rehim MA. Synthesis, antioxidant, and antimicrobial activities of new 2-(1, 5, 6-trimethyl-1H-benzo [d] imidazole-2-carbonyl)-2, 3-dihydro-1H-pyrazole-4-carbonitriles, (1, 3, 4-oxadiazol-2-yl)-1H-benzo [d] imidazol-5-yl) (phenyl) methanones, and (1, 3, 4-oxadiazol-2-yl)-1, 5-dihydro-[1, 2, 4] triazolo [1, 5-a] pyridine8-carbonitriles (QSAR and molecular docking analysis. Egypt Pharm J. 2012, 11(2):80-92.

78. Vargas F, Zoltan T, Rivas C, Ramirez A, Cordero T, Díaz Y, Izzo C, Cárdenas YM, López V, Gómez L, Ortega J. Synthesis, primary photophysical and antibacterial properties of naphthyl ester cinoxacin and nalidixic acid derivatives. J Photochem Photobiol B: Biol. 2008, 92(2):83-90.

79. Hou X, Qiu L, Luo S, Kang K, Zhu M, Yao Y. Chemical constituents and antimicrobial activity of wood vinegars at different pyrolysis temperature ranges obtained from Eucommia ulmoides Olivers branches. RSC adv. 2018; 8(71):40941-40949.

80. AL BARI MA, Sayeed MA, Rahman MS, Mossadik MA. Characterization and antimicrobial activities of a phenolic acid derivative produced by Streptomyces bangladeshiensis a novel specis collected in Bangladesh. Res J Med Medic Sci. 2006, 1:77-81.

81. Ahmad A, Varshney H, Rauf A, Sherwani A, Owais M. Synthesis and anticancer activity of long chain substituted 1, 3, 4-oxadiazol-2-thione, 1, 2, 4-triazol-3-thione and 1, 2, 4-triazolo [3, 4-b]-1, 3, 4-thiadiazine derivatives. Arab J Chem. 2017, 10:3347-3357.

82. Shah R, Verma PK. Synthesis of thiophene derivatives and their antimicrobial, antioxidant, anticorrosion and anticancer activity. BMC chem. 2019, 13(1):1-13.

83. Özdemir A, Altıntop MD, Sever B, Gençer HK, Kapkaç HA, Atlı Ö, Baysal M. A new series of pyrrole-based chalcones: synthesis and evaluation of antimicrobial activity, cytotoxicity, and genotoxicity. Molecules. 2017, 22(12):2112-2117.

84. Čechovská L, Cejpek K, Konečný M, Velíšek J. On the role of 2, 3-dihydro-3, 5-dihydroxy-6-methyl-(4 H)-pyran-4-one in antioxidant capacity of prunes. Eur Food Res Technol. 2011, 233(3):367-376.

85. Diyah NW, Purwanto BT, Siswandono S. Synthesis, molecular docking and antitumor activity of N, N-Carbonylbis (N-ethylbenzamide). Wor J Pharmac Sci. 2015, 3(7):1324-1329.

86. Qaralleh HA, Al-Limoun MO, Khlaifat A, Khleifat KM, Al-Tawarah N, Alsharafa KY, Abu-Harirah HA. Antibacterial and antibiofilm activities of a traditional herbal formula against respiratory infection causing bacteria. Trop J Nat Prod Res. 2020, 4(9):527-534 
87. LaPlante KL, Mermel LA. In vitro activities of telavancin and vancomycin against biofilm-producing Staphylococcus aureus, S. epiderprasadmidis, and Enterococcus faecalis strains. Antimicrob Agents Chemother. 2009, 53(7):3166-3169.

88. Tang HJ, Chen CC, Cheng KC, Toh HS, Su BA, Chiang SR, Ko WC, Chuang YC. In vitro efficacy of fosfomycin-containing regimens against methicillin-resistant Staphylococcus aureus in biofilms. J Antimicrob chemother. 2012,67(4):944-950.

89. Gupta P, Mankere B, Chekkoora Keloth S, Tuteja U, Pandey P, Chelvam $\mathrm{KT}$. Increased antibiotic resistance exhibited by the biofilm of Vibrio cholerae 0139. J Antimicrob Chemother. 2018, 73(7):1841-1847.

90. Andrews JM. Determination of minimum inhibitory concentrations. J Antimicrob Chemother. 2001,48:5-16.

91. Moongkarndi P, Kosem N, Kaslungka S, Luanratana O, Pongpan N, Neungton N. Antiproliferation, antioxidation and induction of apoptosis by Garcinia mangostana (mangosteen) on SKBR3 human breast cancer cell line. J ethnopharmacol. 2004, 90(1):161-166.

92. Ding Y, Li Z, Xu C, Qin W, Wu Q, Wang X, Cheng X, Li L, Huang W. Fluorogenic Probes/Inhibitors of $\beta$-Lactamase and their Applications in Drug-Resistant Bacteria. Angew Chem Int Ed. 2021, 60(1):24-40.

93. Tajkarimi MM, Ibrahim SA, Cliver DO. Antimicrobial herb and spice compounds in food. Food control. 2010, 21(9):1199-1218.

94. Ng WJ, Shit CS, Ee KY, Chai TT. Plant Natural Products for Mitigation of Antibiotic Resistance. In Sustainable Agriculture Reviews, Springer, Cham. 2021, 49:57-91

95. Alhede M, Qvortrup K, Liebrechts R, Høiby N, Givskov M, Bjarnsholt T. Combination of microscopic techniques reveals a comprehensive visual impression of biofilm structure and composition. FEMS Immunol Med Microbiol. 2012, 65(2):335-342.

96. Yang Q, Scheie AA, Benneche T, Defoirdt T. Specific quorum sensingdisrupting activity (A QSI) of thiophenones and their therapeutic potential. Sci rep. 2015, 5(1):1-9.

97. Nemkul CM, Bajracharya GB, Maeda H, Shrestha I. Ethnomedicinal Knowledge Verification for the Antidiarrheal and Antioxidant Effects of Rhus chinensis Mill. Fruits with Identification of Thirty Constituents. Pharmacogn J. 2021,13(1): 37-43.

98. Mujeeb F, Bajpai P, Pathak N. Phytochemical evaluation, antimicrobial activity, and determination of bioactive components from leaves of Aegle marmelos. BioMed Res Int. 2014,1-11.

99. Balaraman S, Nayak N, Subbiah M, Elango KP. Synthesis and antiviral study of novel 4-(2-(6-amino-4-oxo-4, 5-dihydro-1H-pyrrolo [2, 3-d] pyrimidin-3-yl) ethyl) benzamide derivatives. Med Chem Res. 2018, 27(11):2538-2546

100. Kim SH, Choi KC. Anti-cancer effect and underlying mechanism (s) of kaempferol, a phytoestrogen, on the regulation of apoptosis in diverse cancer cell models. Toxicol Res. 2013, 29(4):229-34.

101. Wang J, Fang X, Ge L, Cao F, Zhao L, Wang Z, Xiao W. Antitumor, antioxidant and anti-inflammatory activities of kaempferol and its corresponding glycosides and the enzymatic preparation of kaempferol. PLoS One. 2018, 13(5): e0197563.

102. Grassi L, Maisetta G, Maccari G, Esin S, Batoni G. Analogs of the frog-skin antimicrobial peptide temporin $1 \mathrm{~Tb}$ exhibit a wider spectrum of activity and a stronger antibiofilm potential as compared to the parental peptide. Front Chem. 2017, 5:24-37.

103. Famuyide IM, Aro AO, Fasina FO, Eloff JN, McGaw LJ. Antibacterial and antibiofilm activity of acetone leaf extracts of nine under-investigated south African Eugenia and Syzygium (Myrtaceae) species and their selectivity indices. BMC Complement Altern Med. 2019, 19(1): 141-154.

104. Dutta K, Karmakar A, Jana D, Ballav S, Shityakov S, Panda AK, Ghosh C. Benzyl isocyanate isolated from the leaves of Psidium guajava inhibits Staphylococcus aureus biofilm formation. Biofouling. 2020, 36(8):1000-1017.

105. Patriarca C, Macchi RM, Marschner AK, Mellstedt H. Epithelial cell adhesion molecule expression (CD326) in cancer: a short review. Cancer Treat Rev. 2012, 38(1):68-75.

106. Chen C, Zhao S, Karnad A, Freeman JW. The biology and role of CD44 in cancer progression: therapeutic implications. J Hematol Oncol. 2018, 11(1):1-23.

107. Deep A, Kumar P, Narasimhan B, Ramasamy K, Mani V, Kumar Mishra R, Bakar Abdul Majeed A. Synthesis, antimicrobial, anticancer evaluation of 2-(aryl)-4-thiazolidinone derivatives and their QSAR studies. Curr Top Med Chem. 2015, 15(11):990-1002.

\section{Publisher's Note}

Springer Nature remains neutral with regard to jurisdictional claims in published maps and institutional affiliations.
Ready to submit your research? Choose BMC and benefit from:

- fast, convenient online submission

- thorough peer review by experienced researchers in your field

- rapid publication on acceptance

- support for research data, including large and complex data types

- gold Open Access which fosters wider collaboration and increased citations

- maximum visibility for your research: over 100M website views per year

At BMC, research is always in progress.

Learn more biomedcentral.com/submissions 